\title{
Cognitieve therapie bij eetstoornissen en obesitas
}

Citation for published version (APA):

Jansen, A. T. M., \& Mulkens, S. (2011). Cognitieve therapie bij eetstoornissen en obesitas. In S. M.

Bögels, \& P. V. Oppen (Eds.), Cognitieve therapie: theorie en praktijk (2e editie ed., pp. 357-387). Bohn Stafleu van Loghum. https://doi.org/10.1007/978-90-313-8310-8_13

Document status and date:

Published: 01/01/2011

DOI:

10.1007/978-90-313-8310-8_13

Document Version:

Publisher's PDF, also known as Version of record

Document license:

Taverne

Please check the document version of this publication:

- A submitted manuscript is the version of the article upon submission and before peer-review. There can be important differences between the submitted version and the official published version of record.

People interested in the research are advised to contact the author for the final version of the publication, or visit the DOI to the publisher's website.

- The final author version and the galley proof are versions of the publication after peer review.

- The final published version features the final layout of the paper including the volume, issue and page numbers.

Link to publication

\footnotetext{
General rights rights.

- You may freely distribute the URL identifying the publication in the public portal. please follow below link for the End User Agreement:

www.umlib.nl/taverne-license

Take down policy

If you believe that this document breaches copyright please contact us at:

repository@maastrichtuniversity.nl

providing details and we will investigate your claim.
}

Copyright and moral rights for the publications made accessible in the public portal are retained by the authors and/or other copyright owners and it is a condition of accessing publications that users recognise and abide by the legal requirements associated with these

- Users may download and print one copy of any publication from the public portal for the purpose of private study or research.

- You may not further distribute the material or use it for any profit-making activity or commercial gain

If the publication is distributed under the terms of Article $25 \mathrm{fa}$ of the Dutch Copyright Act, indicated by the "Taverne" license above, 


\section{Cognitieve therapie bij eetstoornissen en obesitas}

Anita Jansen en Sandra Mulkens ${ }^{1}$

\subsection{Inleiding}

In de DSM-IV (APA, 200o) worden drie verschillende eetstoornissen beschreven: bulimia nervosa, anorexia nervosa en eetstoornissen niet anderszins omschreven (eetstoornissen NAO, waaronder ook de eetbuistoornis valt). Obesitas is geen eetstoornis volgens de DSM-IV en ook in de DSM-V - die in 2013 wordt verwacht - zal obesitas niet als eetstoornis opgenomen worden. Desondanks beschouwen wij obesitas als een gedragsprobleem dat in de GGZ behandeld zou moeten worden (Jansen e.a., 2009). Wie blijvend gewicht wil verliezen en daar weinig succes mee boekt, heeft veel baat bij de cognitieve technieken die in dit hoofdstuk beschreven worden. De hier beschreven cognitieve technieken kunnen dus bij elk eet- of gewichtsprobleem worden toegepast.

Een goede toepassing van cognitieve technieken vergt van de therapeut specifieke kennis, vaardigheden en creativiteit. Het is belangrijk dat therapeuten die cognitieve therapie toepassen goed getraind zijn in de cognitieve technieken. Er bestaan veel misvattingen over wat cognitieve therapie is. Het is niet een min of meer vrijblijvende welles-nietesdiscussie over of een idee nu wel of niet klopt. Een goede cognitieve interventie is een uitdagende wetenschappelijke exercitie, zowel voor de patiënt als voor de therapeut. Ideeën of overtuigingen van de patiënt, en hun onderliggende schema's, worden uitgedaagd en empirisch getoetst. Dat is niet eenvoudig. In dit hoofdstuk bespreken wij de basis van cognitieve therapie voor eetstoornissen en obesitas. Eerst volgt een korte beschrijving van de stoornissen. Vervolgens wordt het cognitieve model gepresenteerd, waarna voorbeelden van cognitieve interventies volgen. Met een kort overzicht van het onderzoek naar de effectiviteit van cognitieve therapie bij eetstoornissen en obesitas wordt dit hoofdstuk afgesloten.

1 De auteurs danken Anja Meijboom voor haar bijdrage aan een eerdere versie van dit hoofdstuk. 
Bulimia nervosa (BN) kenmerkt zich door het herhaaldelijk optreden van eetbuien, tijdens welke er een objectief grote hoeveelheid voedsel gegeten wordt en de patiënt controleverlies over het eten ervaart. Patiënten met BN maken zich extreme zorgen om hun uiterlijk en gewicht, daarom treffen ze na een eetbui maatregelen om gewichtstoename te voorkomen. Op grond van de manier waarop er voor gewichtstoename gecompenseerd wordt, worden er twee typen BN-patiënten onderscheiden:

- het purgerende type dat het gewicht onder controle probeert te houden door zelf braken op te wekken, en/of laxeermiddelen en/of diuretica te gebruiken;

- het niet-purgerende type dat tussen de eetbuien door zo min mogelijk probeert te eten, en soms flink gaat bewegen om de gevreesde gewichtstoename zoveel mogelijk te beperken.

De zelfwaardering van BN-patiënten hangt vrijwel uitsluitend af van hun ideeën over het eigen uiterlijk en gewicht. Omdat het eigen lichaamsbeeld meestal negatief is, is de daaraan gekoppelde zelfwaardering doorgaans ook laag. De eetstoornis begint meestal in de adolescentie of jongvolwassenheid. Epidemiologisch onderzoek suggereert dat de prevalentie van BN bij meisjes en jongvolwassen vrouwen ongeveer $2 \%$ is. BN komt veel vaker bij vrouwen voor dan bij mannen; ongeveer in de verhouding 9:1 (Fairburn \& Harrison, 2003). Van het natuurlijke beloop is weinig bekend. Uit diverse studies wordt geconcludeerd dat de eetstoornis in de meeste gevallen niet spontaan geneest en lang kan aanhouden (Fairburn \& Harrison, 2003).

\subsubsection{Anorexia nervosa}

Ook patiënten met anorexia nervosa (AN) maken zich extreme zorgen om hun gewicht. Ondanks het objectieve ondergewicht vinden ze zichzelf te dik en zijn ze vreselijk bang om in gewicht toe te nemen. Om aan de diagnose AN te voldoen, moet er sprake zijn van ten minste $15 \%$ ondergewicht ten opzichte van het normgewicht voor leeftijd, lengte en geslacht, of een body mass index (BMI) lager dan 17,5 (bij volwassen patiënten). Ook moeten er ten minste drie achtereenvolgende menstruele cycli zijn uitgebleven (amenorroe). Amenorroe zal in de DSM-V waarschijnlijk geen diagnostisch criterium meer zijn (EDRS, 2009). Verder moet er sprake zijn van een verstoorde waarneming van het eigen lichaam of het onderschatten of ontkennen van de ernst van het ondergewicht. Ongeveer de helft van de patiënten met AN heeft geregeld last van eetbuien, waarna er meestal ook gebraakt wordt; dit wordt het eetbui/purgerende type genoemd. Heeft de patiënt met AN geen eetbuien en purgeert ze niet, dan wordt er gesproken van het beperkende type. De prevalentie van AN onder meisjes en jongvolwassen vrouwen is $0,5-1 \%$ en de stoornis begint meestal tijdens of vlak na de puberteit. Hele jonge meisjes hebben vaak een goede prognose; zij kunnen snel en goed herstellen van een korte maar krachtige AN-episode. De mortaliteit is erg hoog: circa 10\% van de klinisch opgenomen patiënten met AN 
sterft vroegtijdig - binnen tien jaar na het vaststellen van de eetstoornis. De veronderstelling is dat sneller behandelen na het ontstaan van de stoornis leidt tot een betere prognose (Fairburn \& Harrison, 2003).

\subsubsection{Eetstoornis niet anderszins omschreven}

Indien iemand met een eetstoornis (net) niet aan alle criteria van $\mathrm{AN}$ of $\mathrm{BN}$ voldoet, en er wel duidelijk sprake van een eetstoornis is, dan wordt de diagnose eetstoornis niet anderszins omschreven (NAO) gesteld. Het kan bijvoorbeeld gaan om iemand die aan alle criteria van $\mathrm{AN}$ voldoet, maar die 'slechts' 10\% gewicht verloren heeft. Of iemand die alle kenmerken van BN heeft, maar waarbij de eetbuien niet frequent genoeg optreden. Ook kan het zijn dat iemand een wat vreemde combinatie van eetstoornissymptomen heeft, bijvoorbeeld kenmerken van BN en AN door elkaar heen - deze eetstoornis wordt gediagnosticeerd als eetstoornis NAO.

De eetbuistoornis valt nu, in de DSM-IV, ook nog in de categorie eetstoornissen NAO. In de DSM-V zal de eetbuistoornis als aparte eetstoornis opgenomen worden. Het belangrijkste kenmerk van de eetbuistoornis is net als bij BN, het herhaaldelijk optreden van eetbuien waarbij er een objectief grote hoeveelheid gegeten wordt en er controleverlies over het eten ervaren wordt. Een belangrijk verschil tussen $\mathrm{BN}$ en de eetbuistoornis is dat patiënten met een eetbuistoornis geen drastische maatregelen nemen om te compenseren voor de eetbui. Ze braken niet, gebruiken geen laxantia of diuretica, proberen misschien wel iets minder te eten maar zijn daarin niet echt succesvol. Veel patiënten met de eetbuistoornis hebben overgewicht, mede vanwege het gebrekkige compenseren voor de eetbuien. De prevalentie van de eetbuistoornis is onbekend. Hij wordt geschat op 1-4\% in de gewone populatie, en op $30 \%$ bij mensen met obesitas die in behandeling zijn voor overgewicht (APA, 20oo). Over het natuurlijke beloop van deze eetstoornis is vooralsnog weinig tot niets bekend.

\subsubsection{Obesitas}

Obesitas verwijst naar een grote hoeveelheid lichaamsvet. Een grove maar veelgebruikte maat om vast te stellen of iemand obees is, is de BMI. Deze wordt berekend door het lichaamsgewicht in kilo's te delen door de gekwadrateerde lengte in meters. Wie bijvoorbeeld 110 kilo weegt bij een lengte van 1.69 meter, heeft een BMI van $110 /(1.69)^{2}=38.5$. We spreken van obesitas als de BMI 30 of hoger is. Obesitas is slecht voor de gezondheid: het is een risicofactor voor veel chronische ziekten waaronder hart- en vaatziekten, diabetes en verschillende vormen van kanker. Ook is obesitas een risicofactor voor depressiviteit en lage zelfwaardering. Hoewel obesitas niet als gedragsstoornis in de DSM opgenomen is, zijn er steeds meer psychologen die obesitas behandelen. Obesitas is het gevolg van te veel eten (in relatie tot de hoeveelheid energie die gebruikt wordt) en het lukt veel obesen niet om hun eetpatroon te veranderen: cognitieve gedragstherapie (CGT) kan daarbij behulpzaam zijn (Jansen e.a., 2009). 


\subsubsection{Transdiagnostiek}

Tussen de verschillende eetstoorniscategorieën bestaat flinke 'cross-over', dit wil zeggen dat het merendeel - ongeveer tweederde van het aantal gevallen - van de patiënten heen en weer schuift tussen de verschillende eetstoorniscategorieën. Daarom wordt er tegenwoordig ook wel gesproken van 'transdiagnostiek' (Fairburn, Cooper \& Shafran, 2003). Het uitgangspunt van de transdiagnostiek bij eetstoornissen is dat er sprake is van een eetstoornis die op verschillende tijden verschillende symptomen kan hebben: bijvoorbeeld de aanwezigheid van eetbuien, het hebben van ondergewicht, het wel of niet purgeren, enzovoort. Binnen de eetstoornis variëren de symptomen: als een AN-patiënt zodanig in gewicht toeneemt dat ze een gezond normaal gewicht bereikt, maar ze heeft nog steeds objectieve eetbuien, dan verandert haar diagnose officieel van AN naar BN. Dat is de gesignaleerde 'cross-over'. Maar deze patiënt is natuurlijk niet genezen van de ene eetstoornis en het is ook niet zo dat ze een nieuwe eetstoornis heeft ontwikkeld. De patiënt heeft nog steeds dezelfde eetstoornis, maar de expressie van de eetstoornis is wat veranderd. Sommige experts, zoals Fairburn (2008), pleiten er daarom voor om eenvoudig een 'eetstoornis' te diagnosticeren en de tijdelijke symptomen te specificeren.

\subsection{Cognitief model van eetstoornissen en obesitas}

Protocollaire CGT (Fairburn, 2008) zoals die door de Britse psychiater Christopher Fairburn in de jaren tachtig van de vorige eeuw ontwikkeld werd is de meest succesvolle behandeling van BN. Nationale en internationale richtlijnen stellen daarom dat protocollaire CGT de voorkeursbehandeling voor BN is (Multidisciplinaire richtlijn eetstoornissen, 2006; NICE, 2004). Het model waarop CGT stoelt stelt overgewaardeerde ideeën met betrekking tot uiterlijk en gewicht en de controle hierover centraal. Dit verwijst naar de neiging van eetstoornispatiënten om hun zelfwaardering volledig af te laten hangen van hun evaluatie van het eigen uiterlijk en gewicht, en hoezeer ze in staat zijn om daar controle over uit te oefenen. Dit geldt ook voor AN. Voor volledig en blijvend herstel van een eetstoornis moeten deze overgewaardeerde ideeën worden bijgesteld.

In enkele studies werd gevonden dat het niet veranderen van de overgewaardeerde ideeën over uiterlijk en gewicht sterk gerelateerd is aan terugval in het gestoorde eetgedrag. Fairburn, Peveler, Jones, Hope \& Doll (1993) documenteerden bijvoorbeeld dat van de patiënten die aan het einde van de therapie het minste aantal overgewaardeerde ideeën hadden $9 \%$ terugviel, tegenover $19 \%$ van de patiënten die nog redelijk wat overgewaardeerde ideeën hadden en $75 \%$ van de mensen waarbij veel overgewaardeerde ideeen over uiterlijk en gewicht resteerden.

De kern van Fairburn's (2008) cognitieve model (figuur 13.1) stelt dat gestoord eetgedrag volgt uit die overwaardering van uiterlijk en gewicht, of de gewenste controle daarover. Dit leidt tot minder eten dan nodig is om af te vallen. Die voedselbeperking heeft in veel gevallen - maar niet altijd 
- de ontwikkeling van eetbuien tot gevolg. Eetbuien leiden op hun beurt tot compensatiegedrag; nog minder eten en/of purgeren (braken, laxantiamisbruik). De mogelijkheid om te compenseren vergroot de kans op eetbuien. Ten slotte intensiveren deze factoren (voedselbeperking, eetbuien en compenseren) de overgewaardeerde ideeën over uiterlijk en gewicht. Patiënten die heel weinig eten en geen eetbuien hebben, ontwikkelen ernstig ondergewicht. Opmerkelijk is dat dit voortschrijdend gewichtsverlies de overgewaardeerde ideeën over de controle van uiterlijk en gewicht juist intensiveert. CGT doorbreekt de vicieuze cirkels.

Voor sommige patiënten is deze analyse van overwaardering, lijnen, eetbuien, en compenseren voldoende. Andere patiënten hebben daarnaast last van extreme stemmingswisselingen die eetbuien kunnen uitlokken. Ook zijn er patiënten die lijden onder een ernstig klinisch perfectionisme waardoor de eetstoornis verergert. In deze gevallen kan het van belang zijn te werken aan de stemmingsstoornis - en hoe daarmee omgegaan wordt - of aan het extreme perfectionisme (Shafran, Cooper \& Fairburn, 2002). De CGT die toegepast wordt, sluit altijd nauw aan bij het persoonlijke model van de patiënt, dat opgesteld wordt binnen de grenzen van het overkoepelende model zoals dat in figuur 13.1 is afgebeeld.

Fairburn's CGT bestaat uit twintig sessies voor BN-patiënten en vijftig sessies voor AN-patiënten. Een ruim scala aan gedragstherapeutische technieken wordt aangewend om het eetpatroon, eventuele eetbuien, compensatiegedrag en vooral ook de overgewaardeerde ideeën met betrekking tot uiterlijk en gewicht te veranderen. De gedragstherapie (zoals dieetmanagement, zelfcontroletechnieken, exposure, copingstrategieën, psycho-educatie en het aanleren van probleemoplossende vaardigheden)

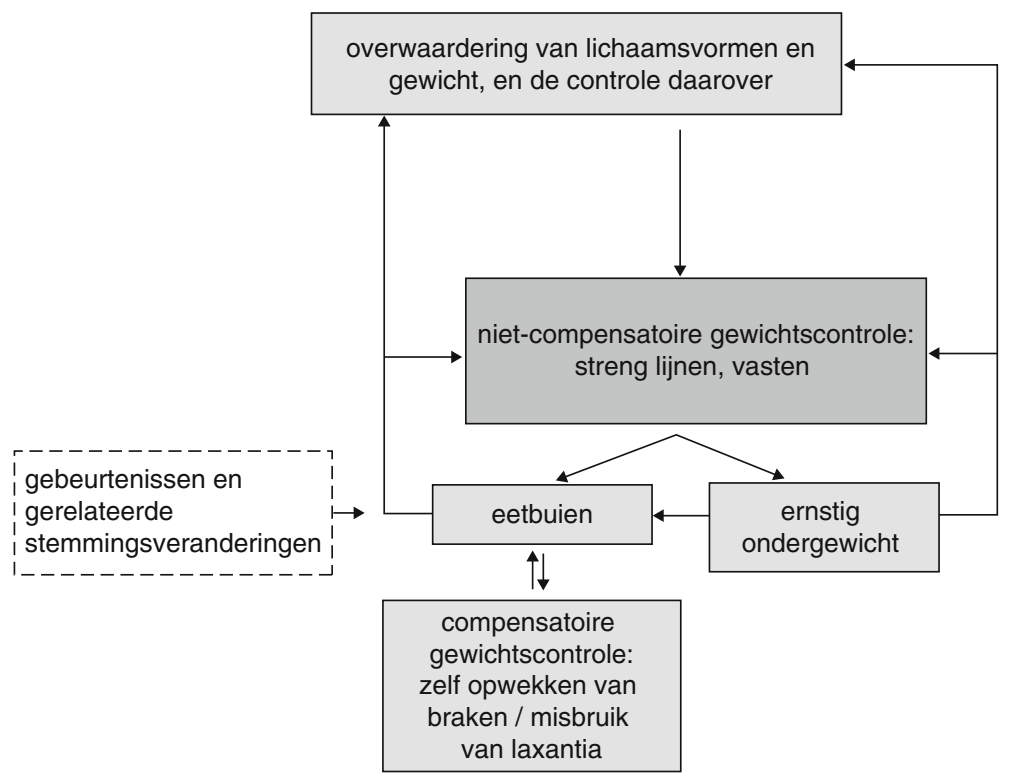

Figuur 13.1

Het 'transdiagnostische' cognitieve gedragsmodel van eetstoornissen van Fairburn (2008). 
gebeurt voornamelijk in het eerste deel van de behandeling, daarna vindt er naast de gedragsinterventies cognitieve herstructurering plaats. Gedragsinterventies kunnen ook tot cognitieve herstructurering leiden, maar vanzelfsprekend is er voor directe cognitieve herstructurering vanwege de intensieve gedragstherapie minder ruimte dan wanneer er uitsluitend cognitieve therapie gedaan zou worden.

In onze polikliniek leggen we de nadruk meer op de cognitieve herstructurering. We behandelen de eetstoornissen NAO, BN, en obesitas voornamelijk met de hier beschreven cognitieve therapie in combinatie met cue exposure (Elgersma, 1998; Jansen, 1998; Jansen \& Meijboom, 1997; Meijboom \& Jansen, 1998). Daarbij gaan we uit van het model van Fairburn (figuur 13.1), maar we trekken de relatie tussen voedselbeperking en eetbuien bij mensen met een gezond gewicht of overgewicht in twijfel, op grond van empirische argumenten. Studies waarin de beperking van voedselinname gemanipuleerd wordt, laten eenduidig zien dat eetbuien niet het gevolg van voedselbeperking zijn.

De verandering van cognities (ideeën, uitgangspunten, overtuigingen) en hun onderliggende schema's is vaak zodanig effectief dat gedrag 'vanzelf' meeverandert, dus zonder extra gedragstherapie. De gedragsveranderingen intensiveren op hun beurt de cognitieve herstructurering. Belangrijk is dat cognitieve uitdagingen en gedragsexperimenten veelvuldig gedaan moeten worden om cognities en schema's daadwerkelijk te veranderen. Veel oefenen met uitdagen en experimenteren (gedragsexperimenten) draagt bij aan het succes van de cognitieve therapie. Een automatische disfunctionele manier van denken is niet zomaar veranderd; daar zijn vele cognitieve exercities voor nodig.

De cognitieve therapie benut verschillende cognitieve technieken om irrationele cognities en hun onderliggende schema's bij te stellen. Onder die cognitieve technieken vallen ook gedragsexperimenten. Verder gebruiken we exposure om irrationele cognities uit te lokken en uit te dagen. Gedragsexperimenten en exposures vergen veel moed van de patiënt; het zijn voor de patiënt vaak uiterst angstaanjagende ideeën die getoetst gaan worden. Vanzelfsprekend vereist dit optimale begeleiding die lief en directief tegelijk is.

Het onderzoeken en veranderen van gedachten die te maken hebben met een lage zelfwaardering en de koppeling van zelfwaardering aan uiterlijk en gewicht kan een belangrijke sleutel voor herstel zijn. Maar ook gedachten die te maken hebben met te veel en te weinig eten, eetbuien en compensatiegedrag, worden door middel van cognitieve therapie bewerkt. Meestal beginnen we met laatstgenoemde gedachten, om vervolgens via lichaamsgerelateerde overtuigingen bij de zelfwaardering terecht te komen.

Volgens ons model is er altijd een situatie te identificeren die tot een eetbui, overeten of voedselbeperking heeft geleid. (De hiernavolgende cijfers verwijzen naar die in figuur 13.2.) Een voorbeeld hiervan is de situatie van de patiënt die zich weegt (1). Als dat tegenvalt, dan zou de patiënt kunnen denken: 'Ik ben veel te zwaar, het is allemaal hopeloos, niets helpt, waar doe ik het allemaal voor'. Deze fatalistische gedachte kan juist ontremmend werken en nodigt uit tot overmatig eten, het dieet helpt immers 
niet. Een AN-patiënt kan in dezelfde situatie denken: 'Ik ben veel te zwaar, ik moet nog beter mijn best doen'. Die restrictieve gedachte nodigt uit tot (nog) minder eten. De situatie is hetzelfde, de constatering 'ik ben veel te zwaar' is hetzelfde, maar de conclusie die de patiënt trekt is heel anders. Die concluderende gedachten leiden tot heel ander gedrag. In beide gevallen ongewenst gedrag. Dat gedrag activeert opnieuw disfunctionele cognities. Overeten bijvoorbeeld kan tot de gedachte leiden 'Ik ben walgelijk dik, alles moet eruit' en dit leidt tot compensatiegedrag, zoals het zelf opwekken van braken, gebruik van laxeermiddelen, sporten of streng lijnen om de 'schade' zoveel mogelijk te beperken. Meestal is het zo dat gedachten die betrekking hebben op het compensatiegedrag de kans op een eetbui vergroten. Op het moment dat de patiënt denkt dat braken makkelijker is als deze extra veel eet (wat ook daadwerkelijk zo is) of dat na braken en laxeren toch alle calorieën weer weg zijn (wat niet zo is) is de kans op ontremmende gedachten en een eetbui groter. Ook extra strenge eetregels maken de kans op een eetbui groter. Hoe strenger de regels hoe sneller ze overschreden worden, wat weer een aanleiding kan zijn voor een ontremmende gedachte als: 'Nu is mijn dag toch al verpest'. Een eetbui, de extreme zorgen om uiterlijk en gewicht en compensatiegedrag dragen allemaal hun steentje bij aan een negatieve zelfevaluatie. Hierdoor neemt de zelfwaardering af (6) en deze lage zelfwaardering verhoogt de kans dat er in een nieuwe situatie ontremmende gedachten ontstaan (2).

\subsection{Behandeling}

\subsubsection{Rationale}

De therapie start met het uitleggen van de rationale (het model) aan de hand van een recente situatie. Indien de patiënt eetbuien heeft wordt meestal begonnen met een eetbui. Als iemand geen eetbuien heeft maar bijvoorbeeld veel moeite met voldoende eten, dan kan een recente 'moeilijke eetsituatie' genomen worden. Het is belangrijk om bij de uitleg het materiaal te gebruiken dat de patiënt aandraagt en om letterlijk de gedachten te noteren die bij de verschillende stappen van het model horen. Al pratend verschijnt het model op het bord. De therapeut sluit zoveel mogelijk bij het taalgebruik van de patiënt aan.

Anne (22) is studente. Naar eigen zeggen was ze altijd al een stevig kind. Ze vertelt dat haar eetprobleem begonnen is toen ze ongeveer achttien was. Na een hevige griep was ze flink afgevallen. Ze kreeg veel complimenten van haar ouders en klasgenoten. Vanaf dat moment werd haar gewicht nog belangrijker voor haar. Ze had er altijd al mee gezeten dat ze niet slank was, nu had ze dan toch eindelijk bereikt wat ze zo graag wilde. Ze deed haar best om weinig te blijven eten en het lukte haar enige tijd om haar lage gewicht te handhaven. Na verloop van tijd kreeg ze echter last van eetbuien. Om 
te voorkomen dat ze dikker zou worden, begon ze opzettelijk te braken na zo'n eetbui. Toen Anne vanwege haar studie op kamers ging wonen, liep het probleem goed uit de hand. Vanaf dat moment is ze alleen nog maar met eten en haar gewicht bezig. Ze heeft vrijwel dagelijks last van eetbuien en na elke eetbui braakt ze. Tussen de eetbuien door probeert ze zo min mogelijk te eten. Constant telt ze calorieën. Ze voelt zich dik en lelijk en wil geen mensen ontmoeten. Haar huidige gewicht is 60 kilo, bij een lengte van 1,70 meter. Haar streefgewicht is 53 kilo. Haar studie lijdt ernstig onder de eetproblemen. Ook heeft ze nog steeds geen vrienden gemaakt. Ze voelt zich erg eenzaam.

Hierna volgt de uitleg van de rationale of het model zoals die met Anne besproken zou kunnen worden. De therapeut modelleert de voorbeelden gelijk op het bord. De cijfers in het voorbeeld verwijzen naar de cijfers in figuur 13.2.

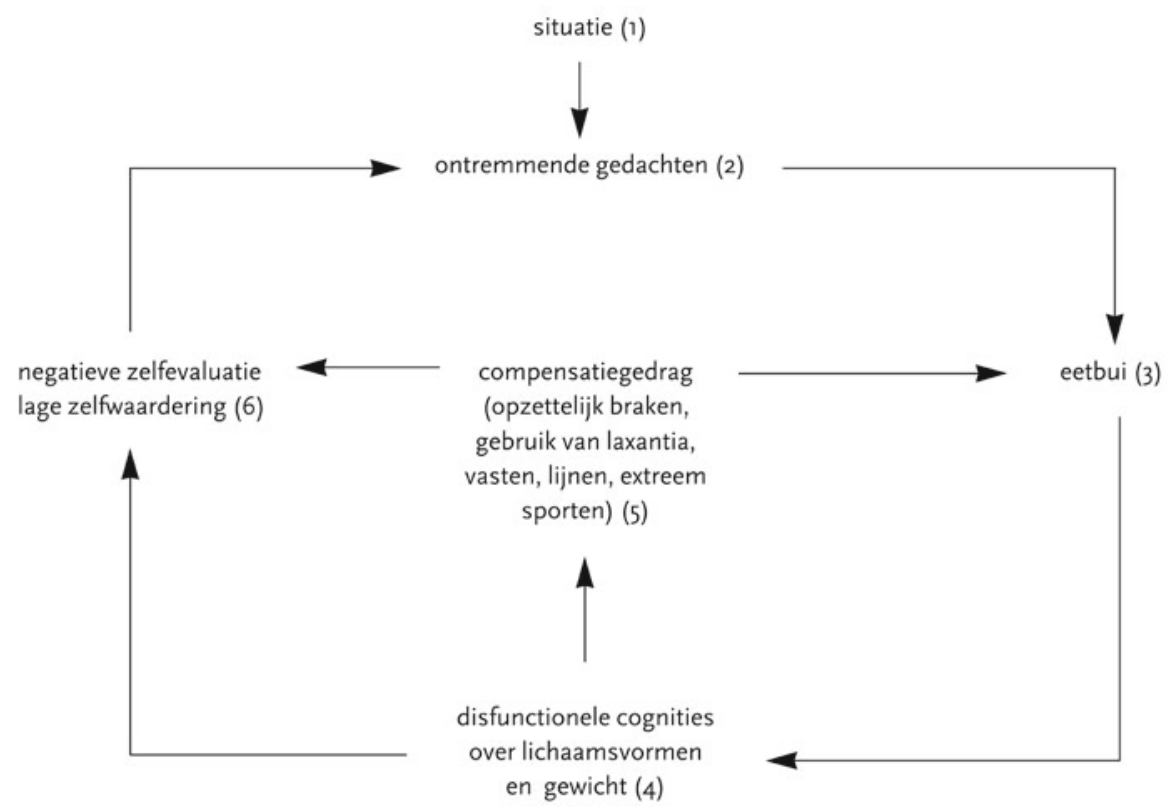

Figuur 13.2

Cognitief model van een eetbui.

Het model van Anne dat op het bord komt te staan zou er uitzien als in figuur 13.3. 


\begin{tabular}{|c|c|}
\hline $\mathrm{T}$ & $\begin{array}{l}\text { Vandaag zal ik je gaan uitleggen hoe de therapie in zijn werk gaat. Daarvoor is het } \\
\text { belangrijk dat we eerst eens kijken hoe je eetprobleem er op dit moment uitziet. } \\
\text { Wanneer is je laatste eetbui geweest? }\end{array}$ \\
\hline$P$ & Vanmorgen. \\
\hline $\mathrm{T}$ & $\begin{array}{l}\text { Vind je het goed dat we die eetbui eens wat nauwkeuriger onder de loep gaan } \\
\text { nemen? }\end{array}$ \\
\hline$P$ & (Aarzelt.) Ja. \\
\hline $\mathrm{T}$ & Wat gebeurde er precies? \\
\hline$P$ & $\begin{array}{l}\text { Ik was alleen thuis en voelde me ontzettend rot. Mijn moeder had me gebeld en } \\
\text { vroeg hoe het met de studie ging. Ik heb toen een opgetogen verhaal opgehangen } \\
\text { over hoe fantastisch alles ging terwijl ik al drie maanden niets meer doe. Toen mijn } \\
\text { moeder ophing voelde ik me echt ontzettend shit. Nou, toen had ik dus een eetbui. }\end{array}$ \\
\hline $\mathrm{T}$ & $\begin{array}{l}\text { Dus je had met je moeder gebeld en haar niet verteld hoe het op dat moment echt } \\
\text { met je ging en je voelde je daarna heel erg rot (situatie: 1) en toen kreeg je die eetbui. } \\
\text { Hoe kwam het dat je door dat rotte gevoel een eetbui kreeg? }\end{array}$ \\
\hline$P$ & $\begin{array}{l}\text { Gewoon. Ik voelde me rot. En het kon me op dat moment allemaal niets meer } \\
\text { schelen. }\end{array}$ \\
\hline $\mathrm{T}$ & Je dacht... \\
\hline P & $\begin{array}{l}\text { Ik dacht: 'Ik voel me nu zo rot, nu mag ik best wel wat eten.' En ik dacht ook: 'Ik doe } \\
\text { toch nooit iets goed, ik kan net zo goed gaan vreten' (ontremmende gedachte: } 2 \text { ). }\end{array}$ \\
\hline $\mathrm{T}$ & En toen kreeg je die eetbui (eetbui: 3)? \\
\hline P & Ja. \\
\hline $\mathrm{T}$ & Wat gebeurde er daarna? \\
\hline$P$ & $\begin{array}{l}\text { Ik heb flink veel gegeten zodat ik makkelijker kon braken en toen ben ik naar de wc } \\
\text { gegaan om alles eruit te gooien. }\end{array}$ \\
\hline $\mathrm{T}$ & Waarom wilde je alles eruit gooien? \\
\hline P & $\begin{array}{l}\text { Omdat het allemaal calorieën zijn waar je hartstikke vet van wordt. Ik ben al veel te } \\
\text { dik. Als ik het er niet uitgooi word ik nog dikker en dan baal ik helemaal van mezelf } \\
\text { (disfunctionele cognities over uiterlijk en gewicht: } 4 \text { ). }\end{array}$ \\
\hline
\end{tabular}


T En daarom heb je gelijk flink veel gegeten, zodat je het makkelijker uit kon braken om zo te voorkomen dat je dikker wordt (compensatie: 5)?

P Ja, dat klopt.

T Wat vond je daarna van jezelf?

P ... echt slecht. Een ongelofelijke slappeling. Ik ben ook bang dat anderen aan me zien dat ik zo'n slappe trut ben die zichzelf niet kan beheersen (negatieve zelfevaluatie en lage zelfwaardering: 6).

$\mathrm{T} \quad$ Je beoordeelt jezelf dan dus heel erg negatief... Als je jezelf zo negatief beoordeelt en je vindt jezelf ook nog eens een slappeling, wat zou er dan gebeuren in een nieuwe situatie?

P Weet ik niet, wat bedoelt $u$ ?

T Nou, als je zo negatief over jezelf denkt, is de kans dan groter of kleiner dat je in een nieuwe situatie weer een eetbui krijgt? ... ik denk groter...?

T (Tekent pijl van 6 naar 2.) Zo is de cirkel rond. Klopt het wat er nu allemaal op het bord staat?

Als het model op het bord staat en therapeut en patiënt het beiden eens zijn dat het zo klopt, wordt uitgelegd hoe cognitieve therapie werkt. Na de algemene uitleg van de therapie (hoofdstuk 2) wordt gekeken of de principes van cognitieve therapie op Anne's eetproblemen kunnen worden toegepast.

$T \quad$ We hebben net besproken dat niet de situatie bepaalt hoe je je voelt en hoe je je gedraagt, maar dat het je gedachte over die situatie is die bepaalt hoe je je voelt en hoe je je gedraagt. Als we nu terugkijken naar het model, zie je dat er veel momenten zijn waarop je gedachten een belangrijke rol spelen. Herken je dat?

P Ja, eigenlijk hebben de meeste van de dingen die we op het bord hebben gezet te maken met gedachten.

T In therapie gaan we onderzoeken of die gedachten kloppen. Laten we eens een gedachte-experiment doen. Ken je iemand in je naaste omgeving die geen eetprobleem heeft? 


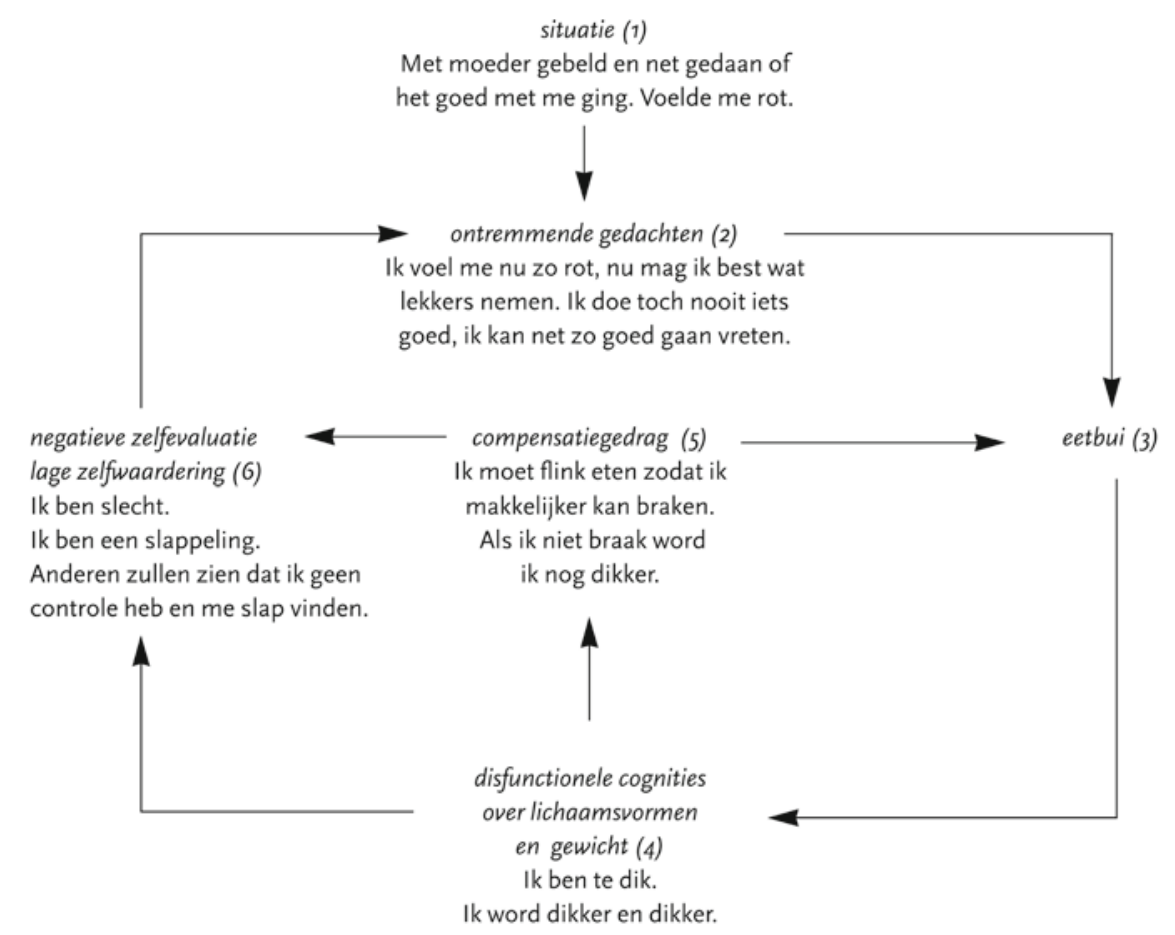

\section{Figuur 13.3}

Het model van Anne.

T Oké, stel je zus zou met je moeder bellen en ze zou je moeder vertellen dat het allemaal goed met haar gaat terwijl ze al drie maanden niet meer studeert. Wat zou je zus denken nadat ze heeft opgehangen?

P Weet niet, ik denk dat ze er wel van zou balen en het stom vindt dat ze erover liegt.

T Wat zou ze gaan doen?

P Waarschijnlijk met haar beste vriendin bellen om erover te praten. Of misschien mijn moeder later bellen om te vertellen dat het eigenlijk helemaal niet zo lekker loopt.

T Dus als je zus in diezelfde situatie terecht zou komen, zou ze niet denken: 'Ik doe toch nooit iets goed, ik kan net zo goed gaan eten.' (Verwijst naar deze gedachte op het bord: 2.) Zij zou denken: 'Stom dat ik erover gelogen heb.' ... We zien dus weer dat eenzelfde situatie heel andere gedrag (eetbui versus bellen met vriendin of moeder) en een heel ander gevoel tot gevolg kan hebben; afhankelijk van hoe er over die situatie wordt gedacht. 
Verschillende gedachten (figuur 13.3: 2, 4, 5, 6) uit het model worden op deze manier besproken om te demonstreren dat er ook andere gedachten mogelijk zijn in dezelfde situatie en dat die andere gedachten zullen leiden tot andere gevoelens en ander gedrag. Het is niet noodzakelijk om alle gedachten die in het model staan onder de loep te nemen; dit is slechts bedoeld om de rationale van cognitieve therapie te onderstrepen. In therapie zal kritisch bekeken worden wat de houdbaarheid is van de gedachten die de patiënt in verschillende situaties heeft.

\subsubsection{Registratie}

$\mathrm{Na}$ de uitleg van de rationale wordt het cognitieve dagboek geïntroduceerd. Samen vullen therapeut en patiënt een aantal moeilijke aan de eetstoornis gerelateerde situaties in, en de bijbehorende gevoelens en gedachten (de eerste drie kolommen van het dagboek). Figuur 13.4 is een voorbeeld van een geheel ingevuld dagboek.

Verder worden er afspraken gemaakt over het wekelijks wegen. De afspraak is dat patiënten met eetstoornissen zich eenmaal per week wegen op een afgesproken dag en afgesproken tijdstip - niet vaker en niet minder vaak. Bij voorkeur is dit's morgens op de dag dat de therapiesessie is gepland, zodat gevoelens besproken kunnen worden en de daarvoor verantwoordelijke gedachten direct in de bijeenkomst bewerkt kunnen worden. Bij extreme weegangst kan eventueel wekelijks tijdens de sessie gewogen worden. Patiënten met een eetstoornis hebben allerlei irrationele ideeën rondom hun gewicht. Bijvoorbeeld dat ze dik worden als ze normaal eten. Door zich wekelijks op een vast tijdstip te wegen kunnen er op termijn verbanden gelegd worden tussen de verandering in eetgedrag en het gewicht. Tegen het einde van de therapie kan er een grafiek gemaakt worden van het wekelijks geregistreerde gewicht. De grafiek die van Anne's gewicht is staat in figuur 13.5.

Voor obese patiënten die af willen vallen is het goed om zich vaker te wegen, om de controle over het gewicht juist te versterken. Bereid de patiënt er wel op voor dat iemands lichaamsgewicht gewoonlijk nogal fluctueert.

\subsubsection{Thema's}

In de eerste fase van de behandeling worden automatische gedachten uitgedaagd met behulp van verschillende technieken. Meestal zijn dit gedachten die over het eetgedrag, compenseren, gewicht en uiterlijk gaan. Door automatische gedachten overtuigend te bewerken zullen symptomen als overeten/eetbuien en voedselbeperking/niet-eten/compenseren in deze fase van de therapie meestal al snel afnemen. Studies tonen aan dat snelle symptoomreductie gerelateerd is aan een beter effect van de behandeling. Soms echter wordt dit doel pas bereikt in of na de tweede fase van de behandeling, waarin meer op schemaniveau wordt uitgedaagd. Een doel van de tweede fase is dat de mogelijke samenhang tussen schema's en sympto- 


\section{Dagboek voor het bijhouden van gedachten}

Datum + Tijdstip: Dinsdag 21 juni $201110.00 \mathrm{mur}$

\section{Situatie:}

Waar ben ik? Met wie? Wat gebeurt er?

Th ben 2 kilo aangekomen.

Gevoel: wanhopig 100

Sterkte van het gevoel (0-100)

Emotie, bijv. angst, woede, verdriet

\section{Automatische gedachten:}

1. Th word dikher en dikher:

100

Geloofwaardigheid (0-100)

\section{Gedrag:}

Hoe reageer ik?

Dieet gaan volgen.

\section{Uitdaging:}

Stel kritische vragen over de automatische gedachten.

Toe weet it dat it dikher en dikher word?

Is het wel eens vaher gebeurd dat it thilo aankwam?

Toe vaak gebeurde dit dan?

Ben ik de laatste jjaar dikher en dikher geworden?

Ts het normaal dat een gewicht schommelt?

Wat is het antwoord op deze vragen?

Dit weet it niet, it han de tochomst niet voorspellen.

Ta, ontelbare keren.

Tedere week ongeveer 8 heer, de laatste 5 jaar: Nijn gewicht schommelt heel erg, maar it ben niet eche dikher geworden.

Weet it niet. Wisschien wel een beetje, bï mij extra vanwege die cetbuien. (dit witzocken!)

\section{Rationele gedachte:}

Zet een rationele gedachte tegenover de automatische gedachten.

\section{Geloofwaardigheid (0-100)}

Us it I hilo aankom dan word ih niet dikher en dikher: ( 80 )

Dat is waarschijnlijh een normale schommeling.? Dit nog witzocken.')

\section{Resultaat:}

Geloofwaardigheid van automatische gedachten (0-100)

Effect op het gevoel (0-100)

\section{Nieuw gedrag:}

Hoe had ik de situatie beter kunnen aanpakken als ik uitga van de rationele gedachten?

\section{1: 40}

onruslig (10), verdrielig (50)

Viet direct gaan lijnen.

Saar de bibliothech gaan om informatie te zochen over schommelingen in gewicht.

\section{Figuur 13.4}

Ingevuld dagboek eetstoornis. 


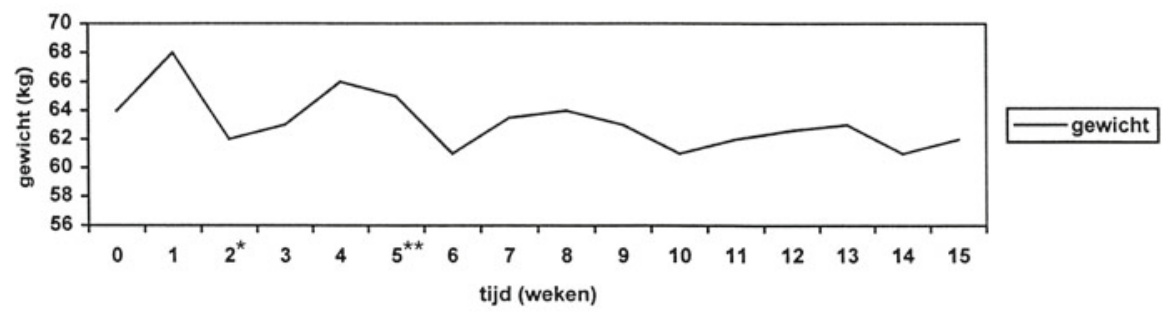

* uitdaging 'eten als ik me rot voel'

th uitdaging experiment 'stoppen met lijnen'

Figuur 13.5

Grafiekverloop van het gewicht.

men ontdekt, uitgedaagd en doorbroken wordt, bijvoorbeeld de koppeling tussen zelfwaardering enerzijds en ideeën over uiterlijk en gewicht anderzijds.

\section{Gedachten rondom overeten en eetbuien}

Veel gedachten rondom 'te veel' eten (inclusief eetbuien) vallen in de categorie ontremmende gedachten. Dit zijn gedachten die min of meer direct tot controleverlies leiden en die grofweg in drie soorten uiteen vallen.

- Overeten om met emoties om te gaan. De emoties zijn vaak negatief, maar ze kunnen ook positief zijn: 'nu mag het, want het is feest'.

'Als ik me rot voel moet ik eten, want dan voel ik me beter.' 'Ik ben zo verdrietig, dat ik niet van het eten af kan blijven.'

'Balen - weer mislukt, wat kan mij het allemaal nog schelen, het lukt me toch niet.'

- Overeten omdat er een persoonlijke eetregel doorbroken wordt.

'Nu ik die boterham met boter en hagelslag heb gegeten is mijn dag verpest. Ik kan nu net zo goed dooreten.'

- Overeten omdat er gecompenseerd gaat worden. 
'Nu ik dat stuk pizza gegeten heb moet ik maar even doorgaan, want dan komt het er tenminste makkelijk uit als ik straks ga braken.'

'Ik gooi al dat eten er straks toch weer uit dus ik kan het er nu flink van nemen.'

'Morgen ga ik weer lijnen, vandaag mag het nog.'

Onze ervaring leert dat het nuttig is om als eerste stil te staan bij de argumenten die vóór een automatische gedachte pleiten. Over het algemeen wemelen deze 'argumenten voor' van de denkfouten en irrationele opvattingen, maar daarmee geven ze ook richting aan waar de informatie gezocht moet gaan worden die tot bijstelling van de automatische gedachte zou kunnen leiden. Er zijn verschillende mogelijkheden om deze ontremmende gedachten bij te stellen.

- Bekijk de korte- en langetermijneffecten van eten om met vervelende gevoelens om te gaan: 'Wat zijn de voordelen en wat zijn de nadelen als je gaat eten zodra je je rot voelt?' Onderzoek of er ook andere manieren zijn om met vervelende gevoelens om te gaan: 'Wat doen mensen die zich rot voelen en geen eetstoornis hebben?’ Meestal komen patiënten met een hele reeks van alternatieve gedragingen om met negatieve gevoelens om te gaan. Hetzelfde geldt voor positieve gevoelens die aanleiding zijn om te overeten. Naast het kritisch onderzoeken van de gedachten is het ook nuttig om de houdbaarheid van een gedachte met behulp van een gedragsexperiment te onderzoeken. Een voorbeeld van een experiment zou kunnen zijn om de invloed van geloofwaardige alternatieve gedachten op de eetbuien en het rotte gevoel te toetsen. De eerste week wordt er op de oude manier met emoties omgegaan (eten) en de tweede week worden alternatieve manieren uitgeprobeerd om met de emoties om te gaan (figuur 13.6).

- Het is handig snel duidelijk te krijgen wat de kenmerken van een 'verpest dieet' zijn. Is het daadwerkelijk zo dat het eten van een stuk chocolade onherstelbare schade aanricht? Heeft 'verboden voedsel' of voedsel waarvan de calorische inhoud onbekend is, magische eigenschappen die er onherroepelijk toe leiden dat iemand meer gaat eten? Hoe kan het dat andere mensen daar geen last van hebben? Stel dat iemand anders zichzelf toe zou staan iets van verboden voedsel te eten, zou dat dan ook tot een eetbui leiden? Wat levert het op om in deze zwart-wittermen te denken (een beetje van de regels afwijken betekent dat het totaal verpest is). Patiënten komen er vaak achter dat juist het strikt hanteren van rigide eetregels makkelijk tot een eetbui leidt. Hoe strenger de regels hoe groter de kans dat ze overschreden worden. Door te experimenteren met het versoepelen of loslaten van de regels (bijv. door gedurende een week af en toe een kleine hoeveelheid verboden voedsel te eten of geen calorieën te tellen of iets te eten waarvan de calorische waarde onbekend is) kan onderzocht worden wat het effect is van strenge en minder strenge eetregels op het aantal eetbuien. 


\section{Experimentformulier}

\section{Invullen voorafgaand aan het experiment}

1 Beschrijving automatische gedachten vóór het experiment:

Us it merot voel moet it eten, want dan voel ik me beter:

Niets helpe als it merot voel.

2 Geef een omschrijving van het experiment:

a Geefeen cijfer ussen 0 en 10 aan het roule gevoel. Toe rotter hoe hoger het cijfen: I week lang eten als its merot vod (boven de 5). Soteer het gevoel uijdens en na het eten.

6. Maak een lijst met alternatieve manieren om met rotte gevoelens om te gaan (bijvi: vriendin bellen, douchen, huilen, hoffie drinhen, enz.) Gen wech lang alternatieven toe passen als ith me rot voel. Noteer het gevoel woor en na.

3 Geloofwaárdigheid automatische gedachten vóór het experiment:

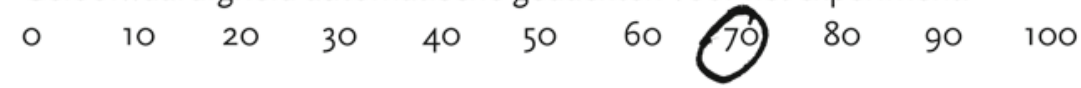

4 Beschrijving alternatieve gedachten vóór het experiment:

Sten helpt niets als it merot voel, andere dingen helpen beter:

Niets helpe als ih me rot vod (dus eten heeft ook geen zin).

5 Geloofwaardigheid alternatieve gedachten vóór het experiment:

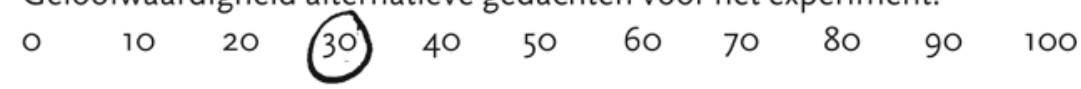

Invullen na afloop van het experiment

6 Hoe is het experiment gegaan?

Tn de te week sheer gegeten. Th weet niet hoe it mï lijdens het eten vod (niets:) maar daarna ooel ik me extra rot!'

In de 20 week 2 keer alternatief toegepast (douchen; met oriendin afgesprohen). Douchen hielp een hlein beetje; niet echt. Maar ih werd er ook niet stechter van. Met mijn oriendin afsprehen hielp wel (rou gevoel van 85 naar 55).

Th heb theer toen ith me cen beetjerot voelde (4) met mijn zus gebeld, toen was het rottegevoel weg.

7 Geloofwaardigheid automatische gedachten ná het experiment:

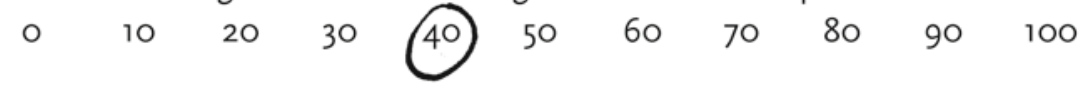

8 Geloofwaardigheid alternatieve gedachten na het experiment:
○ 10
$20 \quad 30 \quad 40 \quad 50 \quad 60$
(7) $80 \quad 90 \quad 100$

Figuur 13.6

Gedragsexperiment over gedachten rondom eten en eetbuien. 
- Bij het uitdagen van gedachten die met compensatiegedrag te maken hebben, blijkt over het algemeen dat braken en andere vormen van compensatiegedrag lang niet zo effectief zijn als patiënten denken. Er blijven na het purgeren meestal wel wat ongewenste calorieën achter in het lichaam, bijvoorbeeld die van de 'snelle suikers'. Ook het 'lijnen' van obesen ('morgen begin ik weer') is meestal niet zo succesvol als gewenst. Zodra gedachten rondom compenseren zijn bijgesteld is de ontremmende eigenschap vaak ook verdwenen.

\section{Gedachten over compenseren}

Het is nuttig om twee belangrijke overtuigingen met betrekking tot compensatiegedrag te bewerken:

- Het idee dat compensatiegedrag het gewicht effectief in de hand houdt.

'Door te braken/laxeren komt al het slechte eten er weer uit.'

- De veronderstelling dat het compensatiegedrag de eetbuien/het overeten en uiteindelijk het gewicht in bedwang houdt.

'Alleen door me aan hele strenge eetregels te houden lukt het me geen eetbuien te hebben.'

'Als ik niet braak, laxeer, vast, sport of lijn, dan krijg ik nog meer eetbuien.' 'Als ik geen streng dieet volg, eet ik te veel.'

Patiënten met een eetstoornis zijn ervan overtuigd dat braken een redmiddel is, omdat het zowel de eetbuien als het gewicht binnen de perken zou houden. Om na te gaan of deze gedachte klopt helpt het om een reconstructie van de eetproblemen te maken; wanneer begonnen de eetbuien? Vaak na een periode van streng lijnen en aanzienlijk gewichtsverlies. Wat gebeurde er met het gewicht en hoeveel tijd ging daar overheen? Wanneer is het braken en/of laxeren begonnen? Wat gebeurde er toen met het gewicht? Hoe ging het verder met de eetbuien? Over het algemeen blijkt dat het gewicht juist meer is gaan schommelen en helemaal niet gezakt is door te compenseren, terwijl de frequentie en de grootte van de eetbuien zijn toegenomen. Braken en laxeren is ook lang zo effectief niet als veel patiënten denken en tevens kan het kwalijke gevolgen hebben. Ook een eetbui kan een aantal lichamelijke gevolgen hebben waar patiënten niet van op de hoogte zijn. In bijlage 13.1 staat daarover wat nuttige informatie. Bespreek wat de voor- en nadelen zijn van het compensatiegedrag en maak hier samen met de patiënt een lijstje van. In figuur 13.7 is een voorbeeld van Anne's lijstje uitgewerkt. 


\begin{tabular}{|c|c|}
\hline voordelen & nadelen \\
\hline $\begin{array}{l}\text { Toel mï opgeluche dired na het braken. } \\
\text { Toel mij daarna verdoofd (geen negatieve emoties). } \\
\text { Twee derde van de eetbui is er toch wit. }\end{array}$ & 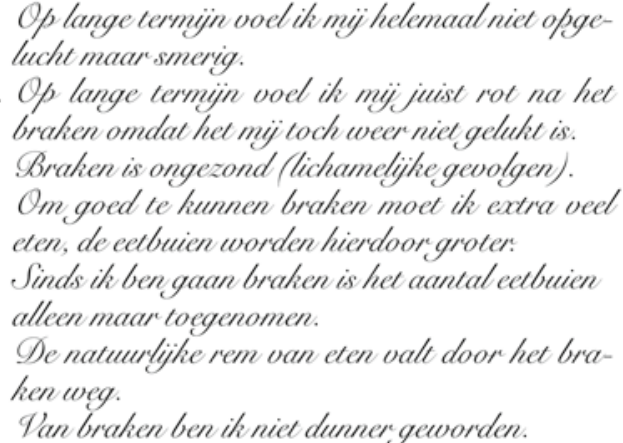 \\
\hline
\end{tabular}

Figuur 13.7

Voor- en nadelen van braken volgens Anne.

In de eerst fase van de behandeling wordt er ook aandacht besteed aan wat een normaal eetpatroon is. Een normaal eetpatroon is regelmatig en bestaat uit drie maaltijden en enkele tussendoortjes. Een mooie vuistregel is dat er maximaal drie uur tussen twee momenten van eten mogen zitten (met uitzondering van de nacht). Wees erop attent dat alcoholische en niet-alcoholische dranken (zoals frisdrank en fruitsappen) ook kilocalorieën leveren. In geval van obesitas is overmatig drinken van frisdranken en fruitsappen vaak een bron van overconsumptie waar men zich meestal niet van bewust is. Een jonge vrouw heeft ongeveer $2100 \mathrm{kcal}$ per dag nodig. Afhankelijk van haar precieze leeftijd en leefstijl (hoe actief ze is) kan dit wat meer of minder zijn. Als een patiënt wil weten hoeveel kcal ze precies kan eten zonder in gewicht toe- of af te nemen, kan ze op zoek gaan naar formules die het energiegebruik berekenen. In bijlage 13.2 staan enkele gangbare formules beschreven. Waarschijnlijk kan de patiënt zelf voldoende informatie op internet vinden. Aan de hand daarvan en/of de bijlage kan zij haar eigen energiegebruik berekenen. Voor elke patiënt is het interessant om te ontdekken dat een hogere BMI leidt tot het gebruik van meer energie. Veel obese patiënten denken dat ze slechts weinig energie verbranden, maar het tegendeel blijkt meestal het geval. Als de obese patiënt denkt een uitzondering te zijn, kan dit uitgedaagd worden - er is slechts een hele kleine kans dat de obese patiënt een afwijkend metabolisme heeft. Maar ook voor de anorectische of boulimische patiënt kan de formule een eyeopener zijn. Laat de patiënt de formule maar eens invullen voor verschillende lichaamsgewichten: 40, 60, 90, 110 kilo. Hoe zwaarder iemand is, hoe meer energie er wordt gebruikt. Moedig uw patiënten ook aan om te onderzoeken wat andere mensen eten en drinken die geen last van een eetstoornis hebben en niet aan de lijn doen. Een patiënt met obesitas kan uitrekenen hoeveel kcal hij of zij niet moet eten om af te vallen, terwijl een anorectische patiënt kan 
uitrekenen hoeveel kcal zij extra moet eten om in gewicht toe te nemen en aan haar normgewicht te voldoen.

De volgende stap is het in de praktijk toetsen of de nieuwe ideeën over het compenseren kloppen. Een nuttig experiment is het volgende: in periode 1 (bijv. week 1 en 2) blijft alles bij het oude. De patiënt noteert het aantal en de grootte van de eetbuien, de manier waarop er gecompenseerd wordt en het lichaamsgewicht. Na deze periode worden er afspraken gemaakt over stoppen met compenseren (hoe en hoe lang). In de tweede periode (bijv. week 3 en 4) worden de eetbuien (aantal en grootte) en het lichaamsgewicht weer genoteerd.

\section{Gedachten rondom uiterlijk en gewicht}

Bij het onderzoeken van de zorgen om uiterlijk en gewicht kunnen meestal drie kerngedachten onderscheiden worden:

- de overtuiging dik te zijn (zoals 'Ik voel me dik, dus ben ik dik' of 'Als ik boven mijn streefgewicht kom, dan ben ik dik');

- de gevolgen van dit vermeende overgewicht (zoals 'Ik ben zo dik dat ik nooit een vriend krijg');

- de relatie tussen gewicht en aantrekkelijk zijn (zoals 'Als ik boven mijn streefgewicht kom, dan ben ik onaantrekkelijk').

De volgende vragen en invalshoeken kunnen helpen om de gedachten rondom uiterlijk en gewicht aan een kritisch onderzoek te onderwerpen.

Wanneer is er objectief sprake van overgewicht? Een BMI tussen 20 en 25 is normaal. Zodra de BMI onder de 20 komt, is er sprake van ondergewicht en een BMI hoger dan 25 duidt op een licht overgewicht (bij een BMI groter dan 27 spreken we echt van overgewicht). De BMI wordt berekend door het gewicht (in $\mathrm{kg}$ ) te delen door de lengte ${ }^{2}$ (in meters). De BMI van Anne is $60 / 1.70^{2}=20,8$.

- Wanneer een BMI tussen 20 en 25 normaal is, zou dit ook in de omgeving van de patiënt zo moeten zijn. Laat de patiënt de BMI van verschillende mensen uit haar omgeving berekenen zodat er een beter beeld ontstaat van wat normaal is.

- Over het algemeen zullen patiënten niet direct blij zijn met het feit dat ze een normaal gewicht hebben. Onderzoek eens wat hun streven naar een lager gewicht ze tot nu toe heeft opgeleverd; een eetstoornis en een sterk schommelend gewicht.

- Bekijk eens of het ideale lichaam dat door de patiënt wordt nagestreefd ook in het wild voorkomt en zo ja, hoe vaak. Laat de patiënt bijvoorbeeld op een zonnige dag op een terras gaan zitten en gedurende een halfuur van de vrouwen die langskomen beoordelen of ze het perfecte figuur hebben of niet. Bij het verzamelen van deze informatie moet het wel heel duidelijk zijn wat de kenmerken zijn van het ideale figuur (therapeut en patiënt spreken dat van tevoren af). Om te voorkomen dat patiënten selectief hun aandacht gaan richten op informatie die overeenkomt met hun oorspronkelijke gedachte en informatie negeren (confirmatiebias) 
die op het tegendeel zou kunnen wijzen, is het noodzakelijk dat ze álle vrouwen die langslopen beoordelen.

- Een experiment zoals beschreven in het hoofdstuk over sociale-angststoornis kan ook hier van pas komen; het laten beoordelen van het uiterlijk (figuur, gewicht) aan de hand van foto's.

Anne zocht twee foto's van zichzelf uit: een waarop ze in normale kleding te zien was en een vakantiefoto waarop ze in badpak stond. Ze stelde een vragenlijst op met vragen als: 'Hoe oud denkt u dat dit meisje is?', 'Welke schoolopleiding volgt dit meisje denkt u?', 'Wat is uw oordeel over de kleding die dit meisje draagt?', 'Welke hobby's zou dit meisje volgens u hebben?', 'Wat vindt u van haar figuur?' De algemene vragen waren toegevoegd om de cruciale vraag over het figuur te maskeren. Anne vroeg zowel haar therapeut als haar zus om deze vragenlijst aan tien mensen voor te leggen, zodat het oordeel van twintig mensen verzameld werd. Deze twintig mensen werd verteld dat de gegevens verzameld werden in het kader van een schoolopdracht (zus) of onderzoek van een student (therapeut). Verder vond Anne het belangrijk dat de foto's alleen werden voorgelegd aan mensen die haar niet kenden en dat er tien mannen en tien vrouwen werden gevraagd. Aan haar therapeut vroeg Anne de foto's niet aan andere therapeuten voor te leggen aangezien die mogelijk op een andere manier over het figuur van iemand oordelen dan de gemiddelde Nederlander. Twee proefpersonen oordeelden dat ze Anne er wat moe uit vonden zien en drie mensen gaven aan dat ze in badpak een wat verlegen, onzekere indruk maakte. Alle gevraagde proefpersonen oordeelden positief over Annes figuur (mooi, slank, prachtig, normaal, enzovoort).

- Als gevoel ('Ik voel me dik') als bewijs wordt aangedragen ('Dus ben ik dik') kan een simpel experiment uitkomst bieden. Laat patiënten op verschillende momenten gevoelsmatig bepalen of ze zich dik(ker) of dun(ner) voelen. Laat tevens registreren wat haar stemming op dat moment is. Laat haar vervolgens op de weegschaal gaan staan om te onderzoeken wat haar gewicht op dat moment echt is. Dit experiment levert meestal op dat patiënten zich dikker voelen als ze een slecht humeur hebben en dat het zich dik voelen niets te maken heeft met daadwerkelijk dik zijn.

De experimenten over dik zijn en dik voelen zijn niet zonder meer van toepassing bij patiënten met overgewicht of obesitas. Hun gevoel dik te zijn is reëel. Maar ook in geval van obesitas gebeurt het vaak dat er meer geleden wordt onder het gewicht als de stemming slechter is. Laat bijvoorbeeld op verschillende momenten de relatie tussen stemming en het gevoel (on)aantrekkelijk te zijn vaststellen. Ook gedachten over de gevolgen van het overgewicht (zoals 'Ik ben zo dik dat ik nooit een vriend krijg') en over 
de relatie tussen gewicht en aantrekkelijk zijn (zoals 'Als ik dik ben, dan ben ik onaantrekkelijk') kunnen uitgedaagd worden.

Concretiseer wat de negatieve consequenties zijn van het huidige gewicht. Bekijk of deze negatieve consequenties reëel zijn en of ze inderdaad toe te schrijven zijn aan uiterlijk en gewicht. Nodig patiënten uit om dit na te gaan. Bekijk bijvoorbeeld hoe ongelukkig, weinig succesvol, enzovoort, dikkere bekende Nederlanders zijn (zoals Tineke de Nooy, Paul de Leeuw of Karin Bloemen) en in hoeverre deze mensen met de vermeende negatieve consequenties te kampen hebben. Onderzoek verder of een lager gewicht de door de patiënten beschreven negatieve consequenties daadwerkelijk zou opheffen.

Het meerdimensionaal maken is een goede methode om te onderzoeken of figuur en gewicht bepalend zijn voor uitstraling of aantrekkelijkheid. Laat de patiënt een zeer aantrekkelijk iemand en een zeer onaantrekkelijk iemand in gedachte nemen. Wat maakt de aantrekkelijke persoon precies aantrekkelijk en wat maakt de onaantrekkelijke persoon precies onaantrekkelijk? Laat patiënten zowel zichzelf als mensen uit haar omgeving beoordelen. Begin met de beoordeling van anderen zodat ze al wat geoefend raakt in het kritisch inschatten en de kans op zwart-witdenken kleiner is als ze zichzelf gaat beoordelen. Precies hetzelfde kan gedaan worden met uitstraling.

Zowel de taarttechniek (paragraaf 3.4.4) als het opstellen van verschillende criteria op de Visueel Analoge Schaal (VAS) van nul tot honderd (paragraaf 3.4.2) zijn hierbij goede methoden. Door bij de taarttechniek na te gaan wat aantrekkelijke mensen aantrekkelijk maakt, ontstaan verschillende punten van de taart. De grootte van de taartpunt geeft aan in welke mate het criterium bijdraagt aan aantrekkelijkheid. De taart die Anne maakte is weergegeven in figuur 13.8 .

In plaats van de verschillende criteria in taartpunten om te zetten kunnen er ook verschillende schalen (VAS) van gemaakt worden, die vervolgens gescoord kunnen worden. Een voorbeeld staat in figuur 13.9.

Lage zelfwaardering en perfectionisme

Als de automatische gedachten die betrekking hebben op de eerste drie thema's (eetgedrag, compenseren, gewicht en uiterlijk) voldoende bewerkt zijn, kan er gestart worden met het uitdagen van het zelfwaarderingsschema. Waarschijnlijk is de koppeling tussen uiterlijk en gewicht enerzijds en zelfwaardering anderzijds al aan bod geweest bij eerdere uitdagingen. Een voorbeeld. 
Figuur 13.8

Taartdiagram van de

factoren die zorgen voor het aantrekkelijk zijn.

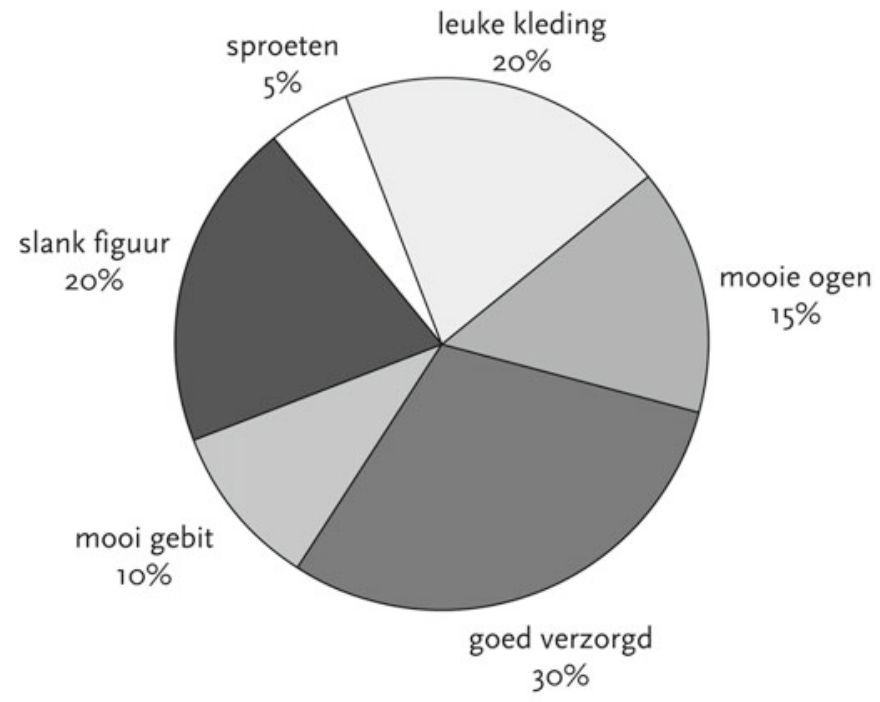

Nu kan er in meer algemene termen op het zelfwaarderingsschema ingegaan worden. Perfectionisme is daarbij een thema dat aan de orde kan komen.

Voor het uitdagen van de lage zelfwaardering worden het hiervoor genoemde meerdimensionaal maken en de taarttechniek aanbevolen en worden een zeer gewaardeerde, sterke, bewonderenswaardige persoon en een zeer slappe, slechte, verachtelijke persoon als uitgangspunten genomen om de verschillende dimensies te bepalen. In figuur 13.9 staat de meerdimensionale uitdaging die Anne daarover maakte.

In sommige gevallen is het bij het uitdagen van het zelfwaarderingsschema noodzakelijk om naar het verleden te kijken en te onderzoeken waar het schema vandaan komt. Patiënten kunnen bijvoorbeeld rapporteren dat ze als kind met hun uiterlijk werden gepest door klasgenoten of dat een familielid de gewoonte had de patiënt 'dikke' of 'dikzak' te noemen. Ook het belang dat door ouders wordt gehecht aan uiterlijk en gewicht kan belangrijke informatie bieden. Door dit soort dingen van vroeger uit te zoeken, wordt de patiënt in de gelegenheid gesteld om als volwassene opnieuw te 'besluiten' of het schema dat ze door vroege ervaringen heeft opgebouwd klopt en in stand gehouden moet worden, of juist niet.

\subsection{Verschillende soorten eetstoornissen}

In grote lijnen is dezelfde cognitieve therapie toepasbaar bij alle eetstoornissen; van AN tot obesitas en alle varianten die daartussen liggen. De 

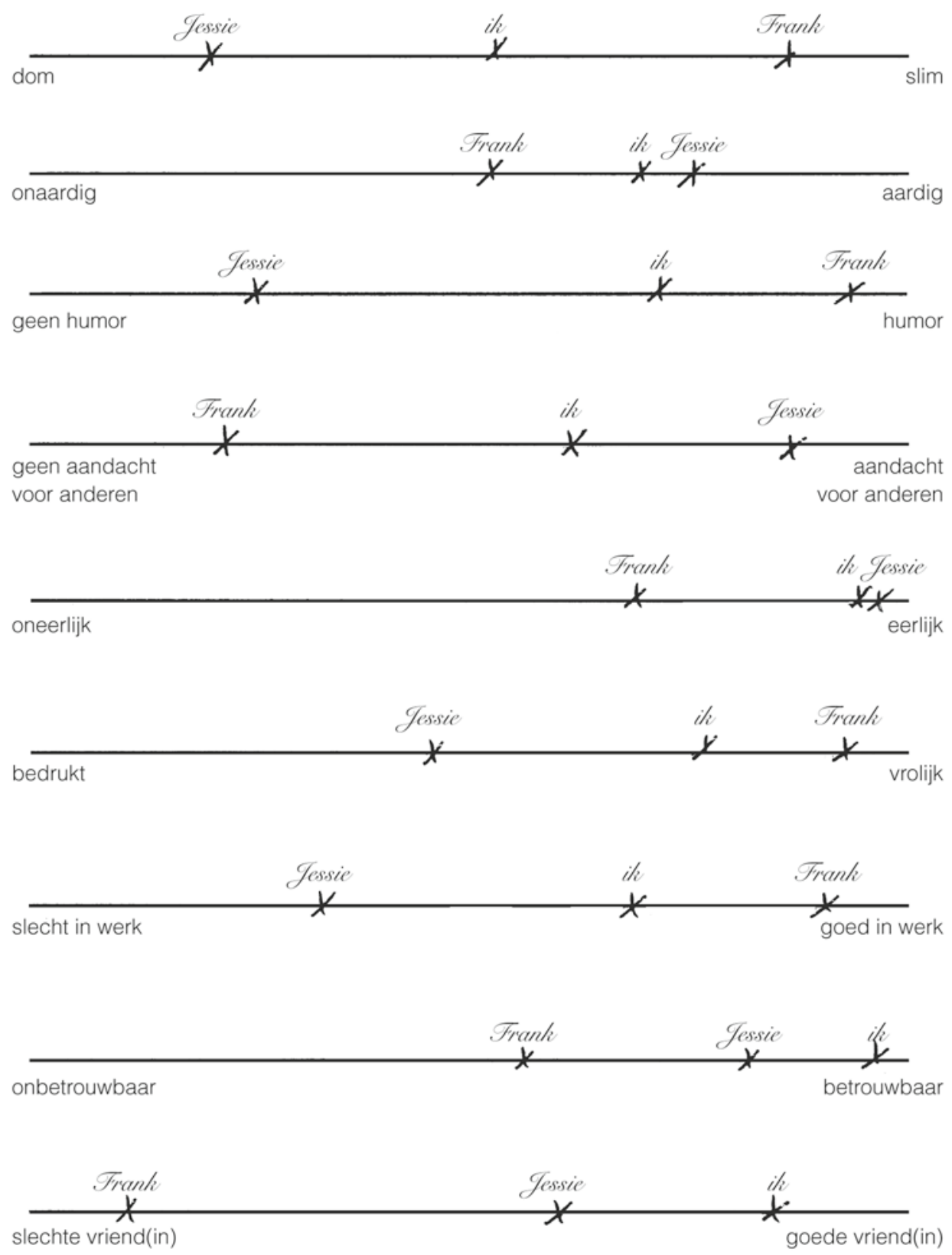

Figuur 13.9

Annes meerdimensionale beoordeling van zelfwaardering.

technieken die toegepast worden zijn hetzelfde bij al deze eetstoornissen: uitdagen en gedragsexperimenten, gericht op eetgedrag, compenseren, uiterlijk, gewicht en de schema's die hiermee verband houden. De specifieke inhoud van de uitdagingen is per patiënt anders: het zijn de specifieke overtuigingen van de patiënt die uitgedaagd worden, en in dat opzicht le- 
vert cognitieve therapie maatwerk. Dat die uitdagingen vaak over bovengenoemde algemene thema's gaan en vaak van eenzelfde strekking zijn doet daar niets aan af.

Uiteraard zijn er ook verschillen tussen de verschillende eetstoornissen. Het lage lichaamsgewicht en de lichamelijke en psychische gevolgen en risico's van het uithongeren, zullen thema's in de behandeling van AN zijn. Het hoge lichaamsgewicht en de lichamelijke en psychische gevolgen en risico's van het overgewicht, zullen thema's in de behandeling van obesitas en overgewicht zijn. Alle patiënten zijn bang om in gewicht toe te nemen, en deze angst is bij de meeste patiënten ongegrond. Echter, een succesvolle behandeling van AN impliceert wel gewichtstoename, maar ook hier is de angst om dik te worden nergens op gebaseerd. De precieze uitdagingen rondom gewichtstoename kunnen daardoor per type eetstoornis verschillen. Een ander verschil tussen de eetstoornissen kan zijn dat de zelfwaardering van de AN-patiënt door het gewichtsverlies juist toegenomen is. Bij een toenemend gewicht kan de zelfwaardering dalen. Bij alle eetstoornissen, inclusief obesitas, is het belangrijk de link tussen het lichaamsgewicht en de zelfwaardering te onderzoeken.

Hoewel alle eetstoornissen draaien om controle over eetgedrag, is het probleem van AN-patiënten een te strenge en rigide controle terwijl patiënten met obesitas en de eetbuistoornis de controle over hun eetgedrag juist kwijt zijn. Patiënten die aan een eetbuistoornis lijden hebben net zulke vreemde ideeën over eten, en net zulke strikte regels als BN-patiënten. In tegenstelling tot $\mathrm{AN}$ - en $\mathrm{BN}$-patiënten lukt het obese patiënten vaak niet de voorgenomen eetregels structureel toe te passen. Bij het bewerken van deze gedachten wordt aangeraden te streven naar een eetpatroon waarbij AN- en BN-patiënten leren de teugels te laten vieren en waarbij obese patiënten juist leren zichzelf meer aan banden te leggen.

De zorgen die obese patiënten over hun lichaamsgewicht hebben, zijn voor een deel reëel: in onze maatschappij worden mensen met overgewicht veelvuldig blootgesteld aan negatieve beoordeling. Er heerst een sterke 'anti-fat bias', en niets menselijks is psychotherapeuten vreemd. Het is daarom niet verwonderlijk dat patiënten ook afkeuring van de therapeut verwachten. De 'anti-fat bias' maakt het ook moeilijker om gerelateerde gedachten uit te dagen. Toch kunnen ook obese ideeën over uiterlijk en gewicht disfunctioneel zijn. Als iemands zelfwaardering volledig van het lichaamsgewicht en de controle over het eten afhangt, dan zullen die overtuigingen uitgedaagd moet worden (Rosen, Orosan \& Reiter, 1995). Interessant is de bevinding dat obese patiënten sterk kunnen verschillen in het tobben en piekeren over hun uiterlijk en gewicht, ook al zijn ze precies even zwaar (Jansen, Havermans, Nederkoorn \& Roefs, 2008).

\subsection{Valkuilen}

Cognitieve therapie bij eetstoornissen kan op een aantal specifieke problemen stuiten. Zo komt het soms voor dat een patiënt de therapeut probeert uit te nodigen uitspraken te doen over haar uiterlijk. Het is niet raadzaam 
om dat te doen. Als patiënten veel waarde hechten aan het oordeel van anderen kan dit eerst in een uitdaging onderzocht worden. Als blijkt dat ze echt geen idee hebben van hoe anderen hen bekijken, kan vervolgens een experiment opgezet worden zoals dat werd beschreven in 'Gedachten rondom uiterlijk en gewicht'. Het is belangrijk dat patiënten precies die informatie verzamelen die voor henzelf geloofwaardig is. Bij sommige patiënten zal dit betekenen dat vreemde mensen om een oordeel gevraagd moet worden, bij andere patiënten dat het juist gevraagd moet worden aan goede bekenden die ze vertrouwen.

Een veelvoorkomende valkuil is dat patiënten zonder overgewicht niet willen stoppen met lijnen maar naar een lager gewicht blijven streven. Ze willen hun huidige gewicht niet accepteren, en een hoger gewicht is al helemaal geen optie. Het is raadzaam hier zeer alert op te zijn, omdat de wens om af te vallen vaak niet door patiënten wordt uitgesproken: dit is als het ware hun geheime agenda. Onderzoek dit thema herhaaldelijk. Nieuwe informatie moet vaak herhaald worden voordat het kwartje echt valt. Pas na vele uitdagingen kunnen patiënten het streven naar een lager gewicht daadwerkelijk opgeven. Het kan ook zijn dat verandering uitblijft omdat er in de uitdagingen belangrijke informatie mist. Bekijk daarom extra zorgvuldig alle argumenten die voor de gedachte pleiten.

Bij AN is gewichtstoename een belangrijk doel in de therapie en er zullen dus afspraken gemaakt moeten worden om gewichtsherstel te realiseren. $\mathrm{Al}$ in een vroeg stadium van de therapie zal er gewerkt moeten gaan worden aan gewichtstoename terwijl de patiënt juist naar het tegenovergestelde streeft. In sommige gevallen is het ondergewicht zo ernstig dat klinische behandeling overwogen moet worden. Er zal in alle gevallen extra aandacht besteed moeten worden aan de motivatie voor gewichtsherstel. Overigens geldt iets vergelijkbaars voor andere eetstoornissen: patiënten met een gezond gewicht zullen gemotiveerd moeten worden om hun 'afvalwens' op te geven, en bij patiënten met obesitas is de motivatie om gezonder te gaan leven en af te vallen onontbeerlijk. Merk op dat motivaties kunnen versterken door een goede cognitieve therapie.

Ook schaamte kan een belemmering zijn bij de behandeling. Patiënten schamen zich veelal voor hun controleverlies over het eten en hun lichaamsvormen en gewicht (ook als dat helemaal niet objectief te hoog is). Dit kan ertoe leiden dat sommige patiënten niet over alles durven te spreken en het vermijden om essentiële informatie te delen.

Ten slotte kan het gebeuren dat patiënten dwangmatig calorieën blijven tellen of hun gewicht blijven controleren. Veel patiënten zijn bang dat ze in gewicht toenemen zodra ze ophouden met controleren. Nadat de gedachten die tot deze gedragingen leiden opnieuw zijn bekeken is het raadzaam gedurende een langere tijd een aantal experimenten te doen. Bijvoorbeeld experimenteren met het eten van calorierijk voedsel of het eten van voedsel waarvan de calorische waarde onbekend is, kan in dit verband nuttige leerervaringen opleveren. Het verloop van het gewicht gedurende de therapie kan opnieuw bekeken worden (figuur 13.5). Bedenk dat gewichtstoename het gevolg is van meer kcal nuttigen dan gebruiken. De oplossing zit hem dus niet zo zeer in het dwangmatig blijven controleren maar in het norma- 
liseren en automatiseren van een acceptabel eetpatroon waarin (normaal) energieverbruik en (normale) energie-inname op elkaar zijn afgestemd (zie 'Gedachten rondom compensatiegedrag').

Voor patiënten met obesitas is het juist wel uiterst heilzaam om hun calorische inname en gewicht nauwkeurig te controleren. Wat dat betreft kunnen we stellen dat obese patiënten juist meer controle over hun eetgedrag moeten leren krijgen terwijl patiënten met de klassieke eetstoornissen juist baat hebben bij een vermindering van controle.

\subsection{Therapie-effectstudies}

Er zijn ons slechts twee studies naar de effecten van pure cognitieve therapie bij eetstoornissen bekend. Veel meer studies werden uitgevoerd naar de effecten van CGT. In een nog ongepubliceerde pilotstudie werd het effect van pure cognitieve therapie bij BN onderzocht en in een andere studie werd cognitieve therapie voor obesitas bestudeerd (Werrij e.a., 2009). Onze $\mathrm{BN}$-studie toonde aan dat cognitieve therapie heel effectief is in de reductie van het aantal eetbuien (90\%) en andere psychopathologie, zowel specifieke eetpsychopathologie als algemene psychopathologie. Het bleek vooral op de langere termijn erg effectief: tot een jaar na de behandeling werd er nauwelijks terugval waargenomen bij de mensen die met cognitieve therapie behandeld waren, terwijl degenen die gedragstherapie (cue exposure met responspreventie) kregen, wel enige terugval lieten zien. Onze obesitasstudie (Werrij e.a., 2009) toonde aan dat cognitieve therapie ook effectief is ter voorkoming van terugval bij obesitas. Naast de groepsbehandeling door diëtisten, kreeg de ene helft van de groep cognitieve therapie en de andere helft bewegingstherapie. Het gewicht van de obesen die met cognitieve therapie behandeld waren nam in het jaar na de behandeling niet toe, terwijl de obesen die bewegingstherapie kregen er een jaar na de therapie weer $26 \%$ van hun verloren gewicht aan hadden zitten (Werrij e.a., 2009). Ook indirect blijkt het positieve effect van cognitieve therapie. Studies waarin CGT met een pure gedragstherapie zonder cognitieve interventies werden vergeleken, tonen dat CGT effectiever is (Fairburn e.a., 1991). Na gedragstherapie is er, zeker op lange termijn, sprake van terugval. Slechts $18 \%$ van de BN-patiënten behandeld met gedragstherapie was na zes jaar nog eetbuivrij en $86 \%$ had nog of weer een eetstoornis (bij $27 \%$ werd de diagnose BN gesteld, bij 59\% de diagnose eetstoornis NAO) (Fairburn e.a., 1995). De meerwaarde van CGT boven gedragstherapie wordt toegeschreven aan de verandering van verstoorde cognities die met de CGT wel en met pure gedragstherapie niet of nauwelijks wordt bereikt.

Dit zijn, voor zover ons bekend, de enige studies waarin cognitieve therapie zonder gedragstherapie werd onderzocht Er zijn daarentegen wel veel studies naar het effect van CGT voor BN gedaan. Veelvuldig werd gedocumenteerd dat CGT de meest effectieve therapie voor BN is (Murphy, Straebler, Cooper \& Fairburn, 2010; Shapiro e.a., 2007; Wilson, Grilo \& Vitousek, 2007). Nationale en internationale richtlijnen melden dat CGT de voorkeursbehandeling voor BN is (Multidisciplinaire richtlijn eetstoornis- 
sen, 2006; NICE, 2004). Door CGT daalt de frequentie van eetbuien en braken met gemiddeld $80 \%$ en circa $55 \%$ van de patiënten is geheel eetbuivrij (Fairburn e.a., 1995; Wilson, 1996). Hoewel er dus nog ruimte voor verbetering is, blijkt CGT voor BN aanzienlijk effectiever te zijn dan vele andere vormen van psychotherapie.

De behandeling van AN werd tot op heden nauwelijks op methodologisch correcte wijze bestudeerd (Fairburn, 2007). Bij veel studies die gepubliceerd zijn is de steekproefomvang te klein om uitspraken te doen en ook ontbreken er nogal eens controlegroepen, met name in oudere studies. Er is nog geen studie gepubliceerd naar de effecten van CGT bij AN. Nog ongepubliceerde data suggereren dat poliklinische CGT (50 sessies) geschikt is voor ongeveer 6o\% van de AN-patiënten met een BMI tussen de 15-17.5. Van die groep knapte $60 \%$ flink op door de CGT, en de terugvalpercentages waren laag (Murphy, Straebler, Cooper \& Fairburn, 2010). Een vorm van 'transdiagnostische' CGT, waarbij de specifieke eetstoornispsychopathologie behandeld wordt en niet een specifieke eetstoornisdiagnose (Fairburn, 2008) boekt goede resultaten bij alle eetstoornissen met een BMI tussen 17,5-26 (Fairburn e.a., 2009). Ook voor de eetbuistoornis lijkt CGT de meest effectieve behandeling (Brownley, Berkman, Sedway, Lohr \& Bulik, 2007; Hay, Bacaltchuk, Stefano \& Kashyap, 2009). De CGT voor de eetbuistoornis bestrijdt vooral het gestoorde eetgedrag en de psychopathologie, maar leidt niet of nauwelijks tot gewichtsverlies. Ook de cognitieve therapie voor obesitas, die wij eerder bespraken, leidde tot slechts een gering verlies van lichaamsgewicht.

Concluderend kunnen we stellen dat over de hele linie van eetstoornissen een goede CGT leidt tot flinke vermindering van (eet)psychopathologie. Op dit moment is CGT het beste dat wij patiënten met eetstoornissen kunnen bieden. Het lijkt erop dat de cognitieve herstructurering bepalend is voor het langetermijnsucces van CGT. Ook patiënten met overgewicht en obesitas profiteren van CGT. Maar er blijven uitdagingen:

- niet iedereen geneest door CGT;

- het gewichtsverlies bij mensen met overgewicht is beperkt.

Het is van groot nut als uitgezocht wordt hoe CGT nog meer eetstoornispatiënten kan genezen, en hoe het voor de patiënten met overgewicht mogelijk is om flink gewicht te verliezen - voor eens en voor altijd.

\section{Literatuur}

American Psychological Association (2000). Diagnostic and Statistical Manual of Mental Disorders (DSM-IV-TR). Washington, DC: APA.

Brownley, K.A., Berkman, N.D., Sedway, J.A., Lohr, K. N. \& Bulik, C.M. (2007). Binge eating disorder treatment: a systematic review of randomized controlled trials. International Journal of Eating Disorders, 40, 337-348.

Eating Disorder Research Society (2009). Presentatie DSMV work group on eating disorders during the Eating Disorder Research Society (EDRS) meeting. New York. 
Elgersma, H. (1998). Cognitieve therapie. In A. Jansen \& A. Meijboom (Red.), Behandelings-strategieën bij bulimia nervosa (pp. 23-33). Houten/Diegem: Bohn Stafleu van Loghum/Cure \& Care Development.

Fairburn, C.G. (2007). Evidence-based treatment of anorexia nervosa. International Journal of Eating Disorders, 37, S26-S30.

Fairburn, C.G. (2008). Cognitive behavior therapy and eating disorders. New York: Guilford Press.

Fairburn, C.G., Cooper, Z., Doll, H.A., O’Connor, M.E., Bohn, K., Hawker, D.M. e.a. (2009). Transdiagnostic cognitive behavioral therapy for patients with eating disorders: a two-site trial with 6o-week followup. American Journal of Psychiatry, 166, 311-319.

Fairburn, C.G., Cooper, Z. \& Shafran, R. (2003). Cognitive behaviour therapy for eating disorders: a 'transdiagnostic' theory and treatment. Behaviour Research and Therapy, $41,509-528$.

Fairburn, C.G. \& Harrison, P.J. (2003). Eating disorders. Lancet, 361, 407-416.

Fairburn, C.G., Jones, R., Peveler, R., Carr, S.J., Solomon, R.A., O'Connor, M.E. e.a. (1991). Three psychological treatments for bulimia nervosa. Archives of General Psychiatry, 48, 463-469.

Fairburn, C.G., Norman, P.A., Welch, S.L., O’Connor, M.E., Doll, H.A. \& Peveler, R.C. (1995). A prospective study of outcome in bulimia nervosa and the long term effects of three psychological treatments. Archives of General Psychiatry, 52, 304-312.

Fairburn, C.G., Peveler, R.C., Jones, R., Hope, R.A. \& Doll, H.A. (1993). Predictors of twelve month outcome in bulimia nervosa and the influence of attitudes to shape and weight. Journal of Consulting \& Clinical Psychology, 61, 696-698.

Harris, J.A. \& Benedict, F.G. (1919). A biometric study of basal metabolism in man. Washington, DC: Carnegie Institute of Washington. Publication No 279, J.P. Lippincot, Philadelphia, PA.

Hay, P.P.J., Bacaltchuk, J., Stefano, S. \& Kashyap, P. (2009). Psychological treatments for bulimia nervosa and binging. Cochrane Database of Systematic Reviews, 4, CDooo562.

Jansen, A. (1998). Lichaamsbeeldtherapie. In A. Jansen \& A. Meijboom (Red.), Behandelingsstrategieën bij bulimia nervosa (pp. 72-83). Houten/Diegem: Bohn Stafleu van Loghum/Cure \& Care Development.

Jansen, A., Havermans, R., Nederkoorn, Ch. \& Roefs, A. (2008). Jolly fat or sad fat? Subtyping non-eating disordered overweight and obesity along an affect dimension. Appetite, 51, 635-640.

Jansen, A., Nederkoorn, C., Roefs, A., Martijn, C., Havermans, R. \& Mulkens, S. (2009). Waarom obesitas in de GGZ behandeld moet worden. GZ-psychologie, 2, 38-44.

Jansen, A. \& Meijboom, A. (1997). Cue exposure voor mensen met eetbuien: meer protocol. Directieve Therapie, 17, 209-229.

Meijboom, A. \& Jansen, A. (1998). Struikelblokken bij cue exposure voor mensen met eetbuien. Directieve Therapie, 18, 378-388.

Murphy, R., Straebler, S., Cooper, Z. \& Fairburn, C.G. (2010). Cognitive behavioral therapy for eating disorders. Psychiatric Clinics of North America, 33, 611-627.

National Institute for Clinical Excellence (NICE) (2004). Eating disorders spatie lang streepje spatie core interventions in the treatment and management of anorexia 
nervosa, bulimia nervosa and related eating disorders. London: NICE. Te vinden op: http://www.nice.org.uk.

Rosen, J.C., Orosan, P. \& Reiter, J. (1995). Cognitive behavior therapy for negative body image in obese women. Behavior Therapy, 26, 25-42.

Roza, A.M. \& Shizgal, H.M. (1984). The Harris Benedict reevaluated: resting energy requirement and body cell mass. American Journal of Clinical Nutrition, 40, 168-182.

Shafran, R., Cooper, Z. \& Fairburn, C.G. (2002). Clinical perfectionism: a cognitive behavioural analysis. Behaviour Research and Therapy, 40, 773-791.

Shapiro, J.R., Berkamn, N.D., Brownley, K.A., Sedway, J.A., Lohr, K.N. \& Bulik, C.M. (2007). Bulimia nervosa treatment: a systematic review of randomized controlled trials. International Journal of Eating Disorders, 40, 321-336.

Trimbos-instituut (2006). Multidisciplinaire richtlijn eetstoornissen. Utrecht: Trimbos-instituut. In opdracht van Landelijke Stuurgroep Multidisciplinaire Richtlijnontwikkeling in de GGZ. ISBN 9052535302.

Werrij, M.Q., Jansen, A., Mulkens, S., Elgersma, H., Ament, A. \& Hospers, H.J. (2009). Adding cognitive therapy to dietetic treatment prevents relapse in obesity. Journal of Psychosomatic Research, 67, 315-324.

Wilson, G.T. (1996). Treatment of bulimia nervosa: When CBT fails. Behaviour Research \& Therapy, 34, 197-212.

Wilson, G.T., Grilo, C.M., Vitousek, K.M. (2007). Psychological treatment of eating disorders. American Psychologist, 62, 199-216. 


\section{Bijlage 13.1 Lichamelijke gevolgen van eetbuien en inadequaat compenseren}

Lichamelijke gevolgen van een eetbui

Door de grote hoeveelheid voedsel die er tijdens een eetbui gegeten wordt, kan de maag extreem uitzetten. Soms komen er dan gaatjes of scheurtjes in de maagwand. Dit kan ernstige maagpijn veroorzaken. Raadpleeg een dokter.

Een pafferig gezicht en opgezwollen handen kunnen het gevolg zijn van een eetbui. Dit is niet gevaarlijk en doet geen pijn, maar kan als zeer onaangenaam ervaren worden.

Lichamelijke gevolgen van purgeren

Veel patiënten met eetstoornissen purgeren. Purgeren verwijst naar opzettelijk braken en misbruik van laxantia en eventueel diuretica, om het voedsel dat gegeten werd weer zo snel mogelijk het lichaam uit te werken. Omdat het purgeren vervelende en soms ook gevaarlijke lichamelijke consequenties kan hebben, wordt het wel beschreven als inadequaat compenseren. Inadequaat compensatiegedrag gaat vaak gepaard met medische klachten. Hierna volgt een overzicht van de meest voorkomende lichamelijke gevolgen van braken, laxantia- en diureticamisbruik.

Door te braken en overmatig laxantiagebruik raakt veel vocht verloren, ook in de bloedvaten. Dit kan leiden tot een verlaagde bloeddruk. Als dat het geval is, kan men zich duizelig, zwak, moe en licht of zweverig in het hoofd voelen. In ernstige gevallen kan flauwvallen het resultaat zijn. Raadpleeg een dokter.

Door het braken en laxantiamisbruik kan er ook een tekort aan elektrolyten (bijv. natrium, kalium) ontstaan. Een tekort aan deze stoffen kan de volgende klachten veroorzaken: hartritmestoornissen, hartkloppingen, spierzwakte, spierkrampen, spierstijfheid, darmjicht, obstipatie en een zwak en moe gevoel. Raadpleeg een dokter bij veel purgeren: in sommige gevallen zijn de hartritmestoornissen zo erg, dat ze tot een hartstilstand leiden.

Regelmatig gebruik van laxantia leidt ertoe dat de darmen lui worden. Omdat de laxeermiddelen ervoor zorgen dat het voedsel door de darmen gaat, hoeven de darmen dit zelf niet meer te doen. Het resultaat is dat er verstopping optreedt zodra er geen laxeermiddelen meer gebruikt worden; de darmen zijn niet meer gewend om zelf te werken. Ten slotte kan het gebruik van een grote hoeveelheid laxantia acuut bloederige diarree veroorzaken.

Herhaaldelijk braken kan ertoe leiden dat de speekselklieren bij de oren opzwellen. Deze zwelling is meestal pijnloos en verdwijnt als de patiënt niet meer braakt. Dit herstel kan echter enkele maanden duren.

Geregeld braken is slecht voor het gebit. Het maagzuur dat door het braken in de mond komt, tast het gebit aan. Het zuur beschadigt het tandvlees en het glazuur van de tanden, waardoor er gaatjes ontstaan en tanden en tandvlees gevoeliger worden. Direct poetsen na bet braken verergert 
de schade alleen maar omdat het zuur als het ware in de tanden gewreven wordt. Het is het beste om na het braken alleen even met water te spoelen.

Braken kan leiden tot irritatie van de slokdarm, een rauwe keel en heesheid. In ernstige gevallen kunnen scheuren of gaatjes in de slokdarm ontstaan. Raadpleeg een dokter.

Effectiviteit van braken: Het doel van braken is om niet in gewicht toe te nemen. Het lijkt er echter op dat gemiddeld ongeveer tweederde van de eetbui uitgebraakt wordt. De rest wordt door het lichaam opgenomen. Vooral voor 'snelle' suikers komt het braken vaak te laat. Deze worden zeer snel in het bloed opgenomen. Braken is dus niet zo effectief als het lijkt.

Effectiviteit van laxantia en diuretica: Laxantia en diuretica worden door mensen met eetstoornissen gebruikt om geen 'vol', opgezwollen gevoel te hebben, niet in gewicht toe te nemen, of om af te vallen. Laxantia en diuretica voeren echter alleen vocht af en leiden niet tot een verlies van vet. Gewichtsverlies na het gebruik van laxantia is dus ongezond vochtverlies en niet vetverlies. 


\section{Bijlage 13.2 Formules om energiebehoefte te berekenen}

Patiënten kunnen zelf berekenen hoeveel energie (kcal) zij per dag nodig hebben om op gewicht te blijven, om in gewicht toe te nemen, of om af te vallen. Hierna volgt wat algemene informatie over energie.

Energie (uitgedrukt in kilocalorieën ( $\mathrm{kcal}$ ) of kilojoules $(\mathrm{kJ}) ; 1 \mathrm{kcal}=4,2$ $\mathrm{kJ}$ ) komt binnen door te eten. Die energie wordt gebruikt om het lichaam te laten functioneren. Meer dan de helft van de energie (65-75\%) is nodig voor basale processen: de automatische processen in het lichaam zoals het kloppen van het hart, ademhalen, enzovoort. Voor de spijsvertering is ongeveer $10 \%$ nodig van de energie die gegeten wordt (dus hoe minder er gegeten wordt, hoe minder energie er voor de spijsvertering gebruikt wordt). De rest van de energie (ca. 20\%) die binnenkomt wordt gebruikt voor lichamelijke activiteit. Wie meer eet dan hij gebruikt (ruststofwisseling + lichamelijke activiteit) neemt in gewicht toe, wie minder eet dan hij gebruikt (ruststofwisseling + lichamelijke activiteit) neemt in gewicht af, en wie evenveel eet als hij gebruikt (ruststofwisseling + lichamelijke activiteit) blijft op hetzelfde gewicht. We noemen dit de energiebalans: de verhouding tussen energieopname (eten) en energiegebruik (ruststofwisseling + lichamelijke activiteit).

Energie komt uit koolhydraten, vetten, eiwitten en alcohol: 1 gram vet levert 9 kcal, 1 gram koolhydraten levert 4 kcal, 1 gram eiwit levert 4 kcal en 1 gram alcohol levert $7 \mathrm{kcal}$. Vitamines en mineralen leveren geen kcal. Voor het lichaamsgewicht maakt het niet uit waar de kcal vandaan komen. Voor iemands gezondheid wel. Streef naar een gevarieerd eetpatroon met ongeveer $25-35 \%$ eiwitten, $15-20 \%$ onverzadigde vetten en $55 \%$ koolhydraten.

Iemands energiebehoefte is afhankelijk van zijn geslacht, leeftijd, lichaamsgewicht en lichamelijke activiteit. Een gemiddelde volwassene gebruikt grofweg per dag 25-30 kcal per kilogram lichaamsgewicht. Iemands precieze energiebehoefte kan berekend worden. Bij voorkeur gebeurt dit door middel van een objectieve meting waarbij de vetvrije massa wordt bepaald, maar dat is vaak niet haalbaar want daar is professionele hulp bij nodig. Voor een eigen berekening kan gebruik gemaakt worden van de formule van Harris \& Benedict (1919), dit is de oudste formule en deze wordt vaak gebruikt:

\footnotetext{
v energiebehoefte in rust voor vrouwen:

V $655,0955+(9,5634 \times$ gewicht in $\mathrm{kg})+(1,8496 \times$ lengte in $\mathrm{cm})-$ $(4,6756 \times$ leeftijd in jaren $)$

v energiebehoefte in rust voor mannen:

v $66,473+(13,7516 \times$ gewicht in $\mathrm{kg})+(5,0033 \times$ lengte in $\mathrm{cm})-$ $(6,775 \times$ leeftijd in jaren $)$
} 
Daarop komt dan nog energie voor activiteit. Afhankelijk van iemands activiteitenniveau wordt bovenstaande vermenigvuldigd met een bepaald getal:
v weinig lichamelijke activiteit $=$ energiebehoefte in $\operatorname{rust} \times 1,2$
v lichte lichamelijke activiteit $=$ energiebehoefte in rust $\times 1,375$
v matige lichamelijke activiteit $=$ energiebehoefte in rust $\times 1,55$
v zware lichamelijke activiteit $=$ energiebehoefte in rust $\times 1,725$
v erg zware lichamelijke activiteit $=$ energiebehoefte in rust $\times 1,9$

De Harris-Benedict formule (1919) is gereviseerd door Roza en Shizgal (1984). Momenteel wordt deze formule meestal gebruikt voor de berekening van iemands energiebehoefte in rust:

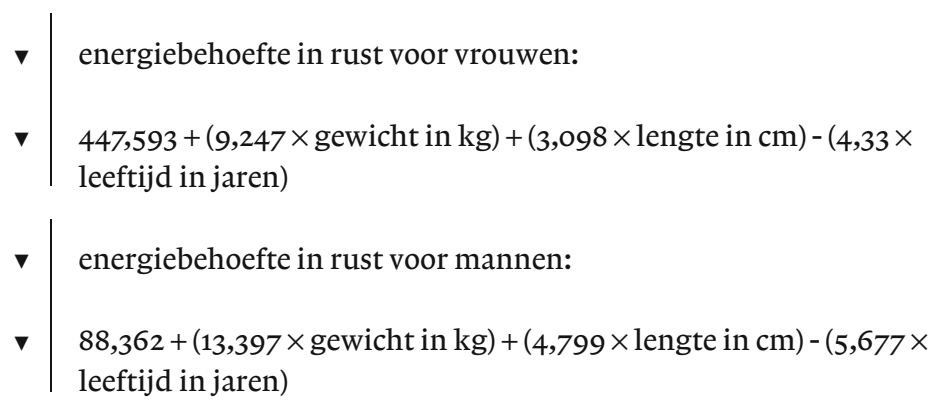

Om iemands totale energiebehoefte te berekenen, komt er nog wat bovenop:

\begin{tabular}{l|l}
$\mathbf{v}$ & zeer geringe activiteit: $+20 \%$ \\
$\nabla$ & geringe activiteit: $+30 \%$ \\
v & gemiddelde activiteit: $+40 \%$
\end{tabular}

Voor kinderen wordt doorgaans de Schofield-formule gebruikt om energiebehoefte in rust te berekenen:

\begin{tabular}{|l|l|l|}
\hline Leeftijd & Jongens & Meisjes \\
\hline 0-3 jaar & $60.9 \times(\mathrm{kg})-54$ & $61.0 \times(\mathrm{kg})-51$ \\
\hline 3-10 jaar & $22.7 \times(\mathrm{kg})+495$ & $22.5 \times(\mathrm{kg})+499$ \\
\hline $10-18$ jaar & $17.5 \times(\mathrm{kg})+651$ & $12.2 \times(\mathrm{kg})+746$ \\
\hline
\end{tabular}


Om de totale energiebehoefte te berekenen, komt er nog wat bovenop:

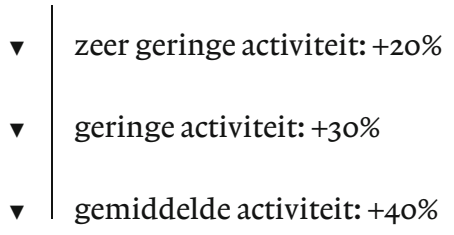

Merk op dat mensen geneigd zijn om hun voedselinname te onderschatten en hun lichamelijke activiteit te overschatten. Misschien is dat voor eetstoornispatiënten anders en soms zelfs tegenovergesteld. Onze lichamelijke activiteit is vaak minder inspannend dan we denken. Bureauwerk (studeren, kantoor) valt in de categorie weinig tot lichte lichamelijke activiteit. Huisvrouwen/mannen verzetten, afhankelijk van hoeveel ze poetsen, lichte tot matige activiteit.

Om een kilo lichaamsvet te verliezen zullen er ongeveer $7000 \mathrm{kcal}$ extra verbrand moeten worden, en om een kilo in lichaamsgewicht toe te nemen zullen er ongeveer $7000 \mathrm{kcal}$ extra gegeten moeten worden. Het is dus eenvoudig uit te rekenen hoeveel kcal er per dag meer of minder gegeten moeten worden om een kilo in gewicht toe te nemen of af te vallen. Als iemand in 1 week een kilo af wil vallen, dan moeten er $1000 \mathrm{kcal}$ per dag minder gegeten worden dan nodig is voor een perfecte energiebalans. En andersom, wie in 1 week een kilo bij wil komen, zal 1000 kcal per dag meer moeten eten dan er nodig is voor een perfecte energiebalans. 